\title{
Results Of Weekly Chemical And Isotopic Monitoring Of Selected Springs In Norris Geyser Basin, Yellowstone National Park During June-September, 1995.
}

By R. O. Fournier ${ }^{1}$, U. Weltman ${ }^{2}$, D. Counce ${ }^{3}$, L. D. White ${ }^{1}$, and C. J. Janik ${ }^{1}$

Open File Report 02-344

Open-File Report 02-344

Available online at: http://geopubs.wr.usgs.gov/open-file/of02-344/

2002

This report is preliminary and has not been reviewed for conformity with U.S. Geological Survey standards or with North American Stratigraphic Code. Any use of trade, firm, or product names is for description purposes only and does not imply endorsement by the U.S. Government.

\section{U.S. DEPARTMENT OF THE INTERIOR}

U.S. GEOLOGICAL SURVEY

1 U.S. Geological Survey, 345 Middlefield Road, Menlo Park, CA 94025

2 National Park Service, Yellowstone Center for Resources, P. O. Box 168, Yellowstone National Park, WY 82190

3 Los Alamos National Laboratory, Hydrology/ Geochemistry/Geology Group, EES-6, MS-D469, Los Alamos, NM 8754 


\section{ABSTRACT}

Each year at Norris Geyser Basin, generally in August or September, a widespread hydrothermal "disturbance" occurs that is characterized by simultaneous changes in the discharge characteristics of many springs, particularly in the Back Basin. During the summer season of 1995, water samples from eight widely distributed hot springs and geysers at Norris were collected each week and analyzed to determine whether chemical and isotopic changes also occurred in the thermal waters at the time of the disturbance. In addition, Beryl Spring in Gibbon Canyon, $5.8 \mathrm{~km}$ southwest of Norris Geyser Basin, was included in the monitoring program.

Waters discharged by four of the monitored hot springs and geysers appear to issue from relatively deep reservoirs where temperatures are at least $270{ }^{\circ} \mathrm{C}$ and possibly higher than $300{ }^{\circ} \mathrm{C}$. At the time of, and for several days after, the onset of the 1995 disturbance, the normally neutral-chloride waters discharged by these four features all picked up an acid-sulfate component and became isotopically heavier. The acid-sulfate component appears to be similar in composition to some waters discharged in 100 Spring Plain that issue from subsurface regions where temperatures are in the range 170-210 ${ }^{\circ} \mathrm{C}$. However, the two monitored springs that discharge acid-chloride-sulfate waters in the 100 Spring Plain region did not show any significant chemical or isotopic response to the annual disturbance. Beryl Spring, and two neutral-chloride hot springs at Norris that appear to draw their water from reservoirs where temperatures are $250{ }^{\circ} \mathrm{C}$ or less, also did not show any significant chemical or isotopic response to the annual disturbance.

After the start of the annual disturbance, chloride concentrations in water sampled from Double Bulger Geyser in the Back Basin increased from about $800 \mathrm{ppm}$ to about 1500 ppm, nearly twice as high as any previously reported chloride concentration in a thermal water at Yellowstone. The isotopic composition of that water precludes an origin of the high chloride by evaporation at atmospheric pressure. One way to account for the unique chemical and isotopic composition of this highly concentrated water is by recirculation of water that had gone through one cycle of adiabatic cooling during upflow (decompressional boiling) back down into the hydrothermal system, where it is reheated to greater than $220{ }^{\circ} \mathrm{C}$. This previously boiled water then undergoes additional cycles of decompressional boiling during subsequent upflow. Another way the unique chemical and isotopic composition of Double Bulger water might evolve is by excess boiling in the formation that results from a decrease in fluid pressure within the channels of upflow.

The annual disturbance at Norris Geyser Basin generally appears to be triggered by a cyclic up and down movement of the boilingpoint curve within the hydrothermal system in response to changes in the potentiometric surface of the cold water that is adjacent to, and interconnected with, that hydrothermal system. Annual disturbance phenomena that are easily recognized at Norris Geyser Basin may not be easily recognized elsewhere in Yellowstone National Park because (1) the neutral-chloride waters at Norris ascend directly from higher-temperature and higherpressure reservoirs $\left(270\right.$ to $>300{ }^{\circ} \mathrm{C}$ at Norris compared to $180-215^{\circ} \mathrm{C}$ at Upper and Lower Geyser Basins) that are capable of producing massive amounts of high-pressure steam, and (2) the clay that makes hot spring and geyser waters become turbid at Norris, heralding the start of the disturbance, comes from acid altered rocks that are widely distributed at intermediate depths at Norris, and that are rare in other geyser basins.

\section{INTRODUCTION}

At Norris Geyser Basin, Yellowstone National Park (YNP), an annual hydrothermal "disturbance" occurs, generally in late August or September, that is characterized by increased turbidity in many hot springs, increased discharge of water and steam, extreme fluctuations in temperatures of pools, and sometimes small hydrothermal explosions (White and others, 1988). Chemical changes at the time of the annual disturbance also have been observed in waters collected from Cistern Spring in the Back Basin of Norris (Fig. 1) (Fournier and others, 1986). Long-term monthly collections and chemical analyses of water from Cistern Spring during 1976-1985 
showed a yearly cycle in which there was a general increase in concentrations of all dissolved constituents over the course of each summer. This is indicative of increased boiling leading up to the disturbance (Fournier and others, 1986; 1992). In contrast, immediately following the onset of these disturbances, Cistern Spring waters have lower chloride and $\mathrm{pH}$, and increased sulfate, indicative of subsurface mixing of neutral-chloride and acid-sulfate waters at the time of the disturbance and for several weeks thereafter (Fournier and others, 1986; 1992).

Prior to our 1995 study only one other hydrothermal feature at Norris (recently informally named "Wistful" Geyser) was known to behave in a similar manner. It normally issues water that has $\mathrm{pH} \approx 7.0, \mathrm{Cl}$ $\approx 675 \mathrm{mg} / \mathrm{kg}$, and $\mathrm{SO}_{4} \approx 25 \mathrm{mg} / \mathrm{kg}$. By chance it was sampled on the first day of the 1990 annual disturbance. That sample had $\mathrm{pH}=2.82, \mathrm{Cl}=527 \mathrm{mg} / \mathrm{kg}$, and $\mathrm{SO}_{4}=133$ $\mathrm{mg} / \mathrm{kg}$ (Fournier and others, 1994). Four days later its $\mathrm{pH}$ had increased to 5.36 , its $\mathrm{Cl}$ was $634 \mathrm{mg} / \mathrm{kg}$, and $\mathrm{SO}_{4}$ was $99 \mathrm{mg} / \mathrm{kg}$ (Fournier and others, 1994). These results clearly show that subsurface mixing of neutral-chloride and acid-sulfate waters occurs in at least two regions of Norris at the time of the disturbance. The present study was undertaken to determine the extent of subsurface mixing and discharge of different thermal waters during these disturbances, and the duration of "mixed" discharge.

\section{MONITORED HYDROTHERMAL FEATURES}

The approximate locations of the eight hydrothermal features that were monitored at Norris Geyser Basin are shown in Figure 1, along with the locations of some other wellknown springs and geysers. In addition, one spring (Beryl Spring) that is located in Gibbon Canyon about $5.8 \mathrm{~km}$ to the southwest of Norris Geyser Basin was included in the monitoring program to see whether the annual disturbance extends to that region of the park. We limited our monitoring activities to a total of nine springs because of constraints on the time that could be devoted to sample collection activities, and because of a limited budget to carry out the supporting chemical and isotopic analyses.
Eight springs at Norris were selected to achieve as widespread a geographic distribution as possible. A major limiting factor in their selection was the distribution of flowing springs at the start of the sampling period in 1995. In the Porcelain Terrace region we monitored "Wistful" Geyser, Perpetual Spouter, and "Carnegie" Spring, the latter issuing at the site of the second Carnegie drill hole (Fenner, 1936); in the Back Basin we monitored Cistern Spring, Double Bulger Geyser, and Porkchop Geyser; in the 100 Spring Plain we monitored Sulfur Dust Spring and "Black" Spring. Quotation marks indicate that a particular spring or geyser has recently been given an informal name that has not yet been officially recognized by the National Park Service.

The nine hydrothermal features selected for monitoring were divided into four groups as follows:
Group 1
a. Beryl Spring
b. Cistern Spring
Group 2 a. Perpetual Spouter
b. "Black" Spring
c. Sulfur Dust Spring
Group 3 a. "Carnegie" Spring at the Carnegie drill site \#2
b. "Wistful" Geyser
Group 4 a. Cistern Spring
b. Double Bulger Geyser
c. Porkchop Geyser

Each of the springs in a given group were sampled on the same day, and the different groups generally were sampled on four successive days. Three days then passed with no sampling. Note that Cistern Spring is in two groups, so it was sampled twice a week. This was done because we intended to use its compositional variations as a key indicator of the onset and progress of the annual disturbance. The dates of sample collection are given in Table 1 .

\section{COLLECTION AND ANALYSIS PROCEDURES}

Waters for use in all the chemical analyses, except for silica, were collected without filtration into $500 \mathrm{ml}$ plastic bottles. For silica analyses, $10 \mathrm{ml}$ of spring water were pipetted into $80 \mathrm{ml}$ of silica free water that had previously been measured into a 125 
$\mathrm{ml}$ plastic bottle. Standard analytical procedures were used for the chemical analyses (Trujillo, and others, 1987). Samples for isotopic analyses were collected in $60 \mathrm{ml}$ glass bottles, with the water completely filling the bottles.

Values for $\mathrm{pH}$ were determined in the field using a portable $\mathrm{pH}$ meter and combination glass electrode calibrated before each measurement with $\mathrm{pH} \mathrm{4,} \mathrm{pH} \mathrm{7,} \mathrm{and} \mathrm{pH}$ 9 buffer solutions. The field $\mathrm{pH}$ readings for the thermal waters were made with the combination electrode immersed in the hot spring and geyser pools. Except for the interval from June 22 (Julian day 173) to July 21 (Julian day 202), a thermister probe that also served to make automatic temperature corrections for $\mathrm{pH}$ measurements was used to measure the temperatures of the hydrothermal features. On June 22 (Julian day 173) the thermister probe for the $\mathrm{pH}$ meter was damaged and a replacement was not obtained until July 22 (Julian day 203). Therefore, during that time interval, a different thermister meter and probe, separate from the $\mathrm{pH}$ meter, was used to measure water temperature. This necessitated making manual temperature corrections for the $\mathrm{pH}$ measurements. Subsequent calibration indicated that the interim thermister equipment gave readings in the field about $2^{\circ} \mathrm{C}$ lower than other temperature probes.

On July 15 (Julian day 196), the combination $\mathrm{pH}$ electrode that had been used up to that time was accidentally broken; it was replaced with a new electrode on July 16 (Julian day 197). It will be shown subsequently that some of the field $\mathrm{pH}$ readings were anomalously high (especially for Sulfur Dust Spring) between the time that the $\mathrm{pH}$ meter temperature probe broke on June 22 (Julian day 173), and the time when a new $\mathrm{pH}$ electrode was installed on July 16 (Julian day 197). Coincident with installation of the new combination $\mathrm{pH}$ electrode the anomalously high field $\mathrm{pH}$ readings returned to normal readings. We suspect that the original $\mathrm{pH}$ electrode began to malfunction at about the time that the $\mathrm{pH}$ meter temperature probe was damaged on June 22 (Julian day 173), and that unreliably high $\mathrm{pH}$ readings were obtained thereafter from that electrode, especially for the more acid waters. However, because we now have no way to verify this, in Figs. 2a-10a all our field $\mathrm{pH}$ data are plotted even though we believe that only the data before June 22 (Julian day 173) and after July 16 (Julian day 197) are likely to be reliable. The interval in doubt is bracketed by vertical dashed lines on these figures and $\mathrm{pH}$ is indicated by small diamonds.

The recorded temperatures of the springs and geysers were measured in the deepest and hottest parts of their pools that could be accessed using a temperature probe with a 1meter reach. For Beryl Spring, Cistern Spring, and Porkchop Geyser, the deepest, and probably hottest, parts of the pools could not be reached with our equipment. However, care was taken always to measure temperature at the same location within each pool so that variations are likely to be significant even if the recorded temperature was less than the maximum temperature. Note that at the elevation of Norris Geyser Basin dilute water boils at about $92{ }^{\circ} \mathrm{C}$.

\section{RESULTS AND DISCUSSION}

The results of the chemical and isotopic analyses are given in Table 1 and summarized in Figs. 2-10. The onset of the hydrothermal event that we set out to study, the 1995 annual disturbance at Norris Geyser Basin, occurred relatively early in that year, on July 29 (Julian day 210). It was marked by the usual widespread increase in hydrothermal activity and the appearance of turbidity in many spring waters.

Two of the monitored springs, "Black" Spring and Sulfur Dust Spring, usually discharge acid-chloride-sulfate waters, typical of the 100 Spring Plain region and Porcelain Basin. The other monitored hydrothermal features usually discharge near neutral, chloride-rich and sulfate-poor waters. Four of these hydrothermal features, Cistern Spring, Double Bulger Geyser, Porkchop Geyser, and "Wistful" Geyser, apparently draw most of their water from a relatively deep reservoir at Norris where temperatures are at least $270{ }^{\circ} \mathrm{C}$, and possibly as high as $310{ }^{\circ} \mathrm{C}$ according to Fournier and others (1976), Fournier (1989), and Fournier and others (1994). The three remaining monitored hydrothermal features, Beryl Spring, "Carnegie" Spring, and Perpetual Spouter, apparently draw most of their water 
from cooler reservoirs where temperatures are $250{ }^{\circ} \mathrm{C}$ or less (Table 2). The estimation of reservoir temperatures is discussed below.

\section{Estimation Of Reservoir Temperatures}

Subsurface reservoir temperatures at Norris Geyser Basin previously have been estimated using a variety of chemical geothermometers and mixing models (Fournier et. al. 1976; Fournier, 1989; Fournier and others 1991; Fournier and others 1994). We have used the silica and $\mathrm{Na} / \mathrm{K}$ data of Table 1 to estimate last temperatures of water-rock equilibration (presumably reservoir temperatures) that are shown in Table 2.

The silica (quartz) geothermometer (Fournier and Rowe, 1966; Fournier and Potter, 1982) works best for near neutral waters issuing from reservoirs where temperatures are in the range $180{ }^{\circ} \mathrm{C}$ to about $230{ }^{\circ} \mathrm{C}$ (Fournier, 1985). Where reservoir temperatures are above $230{ }^{\circ} \mathrm{C}$, some amorphous silica is likely to precipitate underground during upflow from the reservoir to the surface. In this case, quartz geothermometry gives too low an estimated reservoir temperature. An exception is for acid waters because polymerization and precipitation of amorphous silica are inhibited when $\mathrm{pH}$ is less than about 4 (Fournier 1985). When using silica geothermometry to estimate a reservoir temperature it is necessary to make assumptions regarding which silica mineral is controlling dissolved silica (usually quartz is assumed when the temperature is $>180{ }^{\circ} \mathrm{C}$ ), and whether there has been mainly conductive cooling or mainly cooling by adiabatic decompressional boiling during ascent (Fournier, 1985, Fournier, 1991). Table 2 shows the range of possible results with different assumptions.

Many different $\mathrm{Na} / \mathrm{K}$ geothermometers have been proposed for hydrothermal systems (Fournier, 1979; 1981; 1991 and references therein). The most widely ones now in use are by Truesdell (1976), Fournier (1979), Arnórsson (1983), and Giggenbach (1988). Which of these works best in a given area appears to depend on the mineral suite and the structural states of the alkali feldspars that are present in the reservoir rocks (Fournier, 1991). Results using the
Giggenbach (1988), Fournier (1979), and Truesdell (1976) Na/K geothermometers are given in Table 2. The Arnórsson (1983) geothermometer gives results that are very similar to those of the Truesdell (1976) geothermometer.

Figure 11 is a plot of temperatures estimated using the Giggenbach (1988) $\mathrm{Na} / \mathrm{K}$ geothermometer versus temperatures estimated using the quartz geothermometer (Fournier and Potter, 1982). The straight line shows where there is agreement between temperatures estimated by the two geothermometers. Only waters from Beryl Spring and "Carnegie" Spring, which are assumed to have cooled adiabatically, lie on this line. Adiabatic cooling for waters discharged by these springs is reasonable, as they discharge a lot of steam with their waters. All the other spring and geyser waters yield silica temperatures that are significantly lower than the $\mathrm{Na} / \mathrm{K}$ temperatures. The estimated temperature of the reservoir supplying water to Perpetual Spouter is about the same as that of the "Carnegie" Spring reservoir, based on the quartz geothermometer. However, $\mathrm{Na} / \mathrm{K}$ geothermometry puts the Perpetual Spouter reservoir at about $210{ }^{\circ} \mathrm{C}$ using the Truesdell (1976) equation and at about $250{ }^{\circ} \mathrm{C}$ using either the Fournier (1979) equation or the Giggenbach (1988) equation (Table 2 and Fig. 11). We conclude that silica is likely to have precipitated during upflow and prefer the $250{ }^{\circ} \mathrm{C}$ estimated reservoir temperature because of the excellent agreement of the Giggenbach (1988) $\mathrm{Na} / \mathrm{K}$ geothermometer with the silica geothermometer for Beryl Spring and "Carnegie" Spring waters. Similarly, silica is likely to have precipitated from the Cistern Spring, Double Bulger Geyser, Porkchop Geyser, and "Wistful" Geyser waters before reaching the surface. Again, we prefer the estimated reservoir temperatures obtained using the Giggenbach (1988) $\mathrm{Na} / \mathrm{K}$ geothermometer. The $\mathrm{Na} / \mathrm{K}$ geothermometer of Fournier (1979) gives temperatures which are much higher than the maximum likely temperature of the reservoir at Norris, estimated using enthalpy-chloride relations (Fournier, 1989).

The waters issuing from Sulfur Dust Spring have silica temperatures (quartz conductive) of about $200{ }^{\circ} \mathrm{C}$ and those 
issuing from "Black" Spring have silica temperatures ranging up to $205{ }^{\circ} \mathrm{C}$ (quartz adiabatic) or to about $230{ }^{\circ} \mathrm{C}$ (quartz conductive). In contrast, $\mathrm{Na} / \mathrm{K}$ gives temperatures in excess of $300{ }^{\circ} \mathrm{C}$ (Table 2 and Fig. 11). These are acid waters, so amorphous silica is not likely to have precipitated during upflow. We conclude that the reservoir temperatures for these two springs are likely to be about equal to the silica temperatures, and that $\mathrm{Na} / \mathrm{K}$ gives estimated reservoir temperatures that are much too high, as is usual for acid waters that are equilibrating with clay minerals in the absence of feldspars (Fournier, 1991). Note that the lower-temperature acid-chloridesulfate waters at Norris have $\mathrm{Na} / \mathrm{K}$ ratios similar to those in the high-temperature, nearneutral, chloride-rich waters. Therefore, subsurface mixing of these two water types during upflow will markedly affect $\mathrm{Cl} / \mathrm{SO}_{4}$ ratios while $\mathrm{Na} / \mathrm{K}$ ratios remain almost unchanged.

\section{Geochemical Response To The Annual disturbance}

The chemical and isotopic response exhibited by hot-spring and geyser waters to the annual disturbance ranged from insignificant for the initially acid-chloridesulfate waters discharged by Sulfur Dust Spring and "Black" Spring (Figs. 2 and 3) in the 100 Spring Plain area, to very pronounced for the generally near-neutral waters that issue from the high-temperature reservoirs feeding Cistern Spring, Double Bulger Geyser, Porkchop Geyser, and "Wistful" Geyser (Figs. 4-7). Near-neutral waters issuing from the lower-temperature reservoirs feeding "Carnegie" Spring, Perpetual Spouter, and Beryl Spring (Figs. 8-10) showed little response to the disturbance.

The large upward spike in $\mathrm{pH}$ exhibited by Sulfur Dust Spring over the period June 23-July 14 (Julian days 174-195) shown in Figure $2 \mathrm{a}$ is contrary to what would be expected from the nearly constant $\mathrm{Cl}$ and $\mathrm{SO}_{4}$ concentrations measured in the waters collected at the same time from this spring (Fig. 2b). It also is contrary to the $\mathrm{pH}$ measurements made in the laboratory (Fig. 2a and Table 1). As discussed above, we believe that the anomalously high field $\mathrm{pH}$ measurements are in error. However, an argument can be made that the high field $\mathrm{pH}$ readings for Sulfur Dust Spring might be accurate (not the result of a faulty electrode reading). During the period that anomalously high $\mathrm{pH}$ readings were made in Sulfur Dust's pool there was no detected problem with the 3-buffer calibration of the electrode before each $\mathrm{pH}$ reading. Also, with the exception of two anomalously high $\mathrm{pH}$ readings in "Black" Spring (Fig. 3a), and one anomalously high reading in Cistern Spring (discussed below), consistently "reasonable" $\mathrm{pH}$ readings were made in other thermal pools on the same day, and over the same time span that anomalously high $\mathrm{pH}$ readings were made for Sulfur Dust waters. If the anomalous high field $\mathrm{pH}$ readings for Sulfur Dust and "Black" are real (not the fault of a malfunctioning electrode) the $\mathrm{pH}$ of the samples will have had to change (become lower) in the sample bottles after collection. One way for this to occur would be for the deep Sulfur Dust Spring water (and "Black" also) to carry a nearly constant concentration of colloidal sulfur which usually is completely converted to sulfuric acid by bacteria activity before reaching the surface pool. If, for some unexplained reason, for a period of about three weeks, this colloidal sulfur was not converted to sulfuric acid underground, it could have been converted to sulfuric acid in the sample bottle by bacterial activity between the time of collection and the time of laboratory analyses because the water samples were not filtered. Again, we stress that we do not advocate this latter explanation because the return to "normal" $\mathrm{pH}$ readings in both Sulfur Dust Spring and "Black" Spring was coincidental with the replacement of the original $\mathrm{pH}$ electrode with a new electrode.

Like the Sulfur Dust results, $\mathrm{Cl}, \mathrm{SO}_{4}$ and $\mathrm{pH}$ in "Black" Spring's waters, measured in the laboratory, remain essentially constant even though some $\mathrm{pH}$ readings were anomalously high (Fig. 3). Again, we believe that the best explanation for the $\mathrm{pH}$ anomaly is a malfunctioning $\mathrm{pH}$ electrode that was used with the portable $\mathrm{pH}$ meter. It is puzzling, however, why the upward $\mathrm{pH}$ spike for Sulfur Dust Spring was so much greater and started sooner than that for 
"Black" Spring. Sulfur Dust Spring normally has a slightly lower $\mathrm{pH}$ and much lower temperature than "Black" Spring. Perhaps the higher temperature of "Black" Spring allowed a faulty $\mathrm{pH}$ electrode to come closer to equilibrium during the relatively short time of the in-pool measurement than occurred for Sulfur Dust Spring.

The waters from "Black" Spring are slightly lower in $\mathrm{Cl}$ and are isotopically heavier than those collected from Sulfur Dust Spring (Table 1 and Figs. 2d, 3d, and 12). The isotopically heavy nature of "Black" Spring relative to Sulfur Dust can be explained in part by different degrees of mixing of isotopically light and $\mathrm{Cl}$-rich waters with isotopically heavy and $\mathrm{Cl}$ poor waters, and in part by a greater degree of evaporative steam loss from "Black" Spring. A relatively high degree of evaporation from "Black" Spring, compared to Sulfur Dust Spring, seems reasonable because of its much greater surface area, higher temperature (compare Figs. 2a and 3a), and, during our sampling campaign, very low rate of discharge. Prior to evaporation "Black" Spring waters would have contained even less $\mathrm{Cl}$ than our reported values. Our data show that, in general, the thermal waters at Norris which contain less $\mathrm{Cl}$ generally have heavier $\delta \mathrm{D}$ values.

Water collected from the Y-12 drill hole probably provides the best indication of the chemical and isotopic composition of the deepest and hottest fluid beneath the Norris Geyser Basin. It has $\delta \mathrm{D} \approx-148 \%$ o,$\delta^{18} \mathrm{O} \approx$ $-16.5 \%$, and $\mathrm{Cl} \approx 548 \mathrm{ppm}$ (unpublished data, U. S. Geological Survey files, sample YJ93-17, collected July 29, 1993). During upflow from the deep reservoir, this water apparently mixes with water in shallower reservoirs, generally becoming more dilute in $\mathrm{Cl}$ and isotopically heavier. Sulfur Dust Spring water is about $6 \%$ o heavier in $\delta \mathrm{D}$ and about $1.5 \%$ o heavier in $\delta^{18} \mathrm{O}$ than the Y-12 water. On a plot of $\delta^{18} \mathrm{O}$ versus $\delta \mathrm{D}$, Sulfur Dust Spring water has about the same $\delta \mathrm{D}$ as local meteoric water, but is about $4 \% o$ heavier in $\delta^{18} \mathrm{O}$ (Fig. 12a). In contrast, the $\delta \mathrm{D}$ of "Black" Spring water is about $17 \%$ heavier than local meteoric water (about 23 $\% o$ heavier than $\mathrm{Y}-12$ ) while its $\delta^{18} \mathrm{O}$ is about $8 \%$ o heavier than local meteoric water (about $6 \%$ o heavier than Y-12) (Fig. 12b). For comparison, in Figure 12 the data point labeled "Vermilion Spg" shows a typical isotopic composition of a low-chloride, acidsulfate water in a steam-heated, nonoverflowing pool.

Cistern Spring (Fig. 4) exhibited a slow decrease in $\mathrm{pH}$ and $\mathrm{Cl} / \mathrm{SO}_{4}$ for about 15 days prior to the start of the annual disturbance (Figs. 4a and 4c). This trend of changing composition abruptly became much more pronounced on the day of the disturbance and continued for 30 days thereafter. Similar precipitous changes in $\mathrm{Cl} / \mathrm{SO}_{4}$ and $\mathrm{pH}$ had been noted at the times of other annual disturbances (Fournier and others, 1986). There also was a small and short-lived mixing event 20 days prior to the start of the disturbance (day 190), during which Cistern Spring's water exhibited decreased $\mathrm{Cl}$ and increased $\mathrm{SO}_{4}$ (Fig. 4b). This event was accompanied by a decrease in $\mathrm{Na} / \mathrm{K}$ (Fig. 4c). We expected to see an accompanying decrease in $\mathrm{pH}$ at the time of this small event, but instead recorded an anomalously high $\mathrm{pH}$ reading (Fig. 4a). As noted above, we suspect that this high $\mathrm{pH}$ on day 190 may be erroneous, the result of a malfunctioning electrode.

Isotopic changes in Cistern Spring's waters generally parallel the variations in $\mathrm{Cl}$ and $\mathrm{SO} 4$. Both $\delta \mathrm{D}$ and $\delta^{18} \mathrm{O}$ become heavier as $\mathrm{Cl}$ decreases and $\mathrm{SO}_{4}$ increases (compare Fig. $4 \mathrm{~d}$ with $4 \mathrm{~b}$ and $4 \mathrm{c}$ ). This clearly shows that the sulfate-rich component of the mixed water is isotopically relatively heavy. We suspect that the upward spike in $\delta^{18} \mathrm{O}$ on day 176 (Fig. 4d) is not real because it is not accompanied by any other chemical anomaly. In contrast, the small $\delta^{18}$ O spike on day 190 probably is real because it is accompanied by distinct $\delta \mathrm{D}, \mathrm{Cl} / \mathrm{SO}_{4}$ and $\mathrm{Na} / \mathrm{K}$ anomalies (Fig. 4c). The decreasing trend in $\delta \mathrm{D}$ from day 173 to 180 is not accompanied by other major chemical changes, and, at this time, we can offer no explanation for this anomaly. 
On a diagram showing $\delta^{18} \mathrm{O}$ versus $\delta \mathrm{D}$ for all Norris waters, Cistern Spring waters show considerable variation, but all plot with the heavier waters (Fig. 12c). These isotopic variations probably result in part from different amounts of mixing of different waters, and in part from different degrees of boiling with steam separation during upflow.

Double Bulger Geyser's waters exhibited dramatic and unexpected changes over the monitored period. Prior to the annual disturbance chloride values were very irregular, ranging up and down from a minimum of $665 \mathrm{ppm}$ to a maximum of 849 ppm (Fig. 5b and Table 1). Other dissolved constituents, including $\mathrm{Br}, \mathrm{Na}, \mathrm{K}$, and $\mathrm{SO}_{4}$, show similar peaks and valleys when plotted versus Julian day (Fig. 13), so we conclude that those ups and downs in $\mathrm{Cl}$ concentration were real, and probably resulted from different degrees of steam separation during flow to the surface. However, there was a general trend of decreasing $\mathrm{Cl} / \mathrm{SO}_{4}$ prior to the annual disturbance (Fig. 5c), so some subsurface mixing of different waters was occurring. On the day of the annual disturbance there was an increase in $\mathrm{Cl}$ and $\mathrm{Cl} / \mathrm{SO}_{4}$.(Figs. 5b and 5c). This is contrary to what was observed in the Cistern Spring and "Wistful" Geyser waters (Figs. 4b and $4 c$ and Figs. $7 b$ and $7 c$ ). Shortly after the start of the annual disturbance, the water level in Double Bulger dropped to a level too low to sample, although discharge of steam continued, and upward splashing of water from deep within the vent could be seen. By eleven days after the start of the annual disturbance the water level once again was high enough to sample. By then Double Bulger Geyser's $\mathrm{Cl}$ had attained a value of 1444 ppm, which was about twice as high as any previously recorded in a Yellowstone thermal water (extensive tabulations of chemical analyses are given in Gooch and Whitfield, 1888; Allen, and Day, 1935; Rowe and others, 1973; Thompson and others, 1975; Thompson and Yadav, 1979; and Thompson and DeMonge, 1996). However, at the same time the $\mathrm{Cl} / \mathrm{SO}_{4}$ ratio and $\mathrm{pH}$ both decreased (Figs. 5a and 5c), indicating addition of an $\mathrm{H}_{2} \mathrm{SO}_{4}$ component to the water. The addition of an $\mathrm{H}_{2} \mathrm{SO}_{4}$ component after the start of the disturbance also is evident in Figure 13, which shows a dramatic increase in $\mathrm{SO}_{4}$ while the major cations, $\mathrm{Na}$ and $\mathrm{K}$, continue to reflect mainly variations in $\mathrm{Cl}$ and $\mathrm{Br}$.

Figures 14 and 15 are plots of $\delta \mathrm{D}$ and $\delta^{18} \mathrm{O}$ respectively versus $\mathrm{Cl}$ for Double Bulger Geyser's waters compared with data for the other springs collected in 1995. Also shown are data for Echinus Geyser which discharges the largest volume of acid-sulfatechloride water of any feature at Norris. For comparison, Y-12 drill hole water (condensed total flow) and local meteoric water also are plotted in Figures 14 and 15. In these figures the labeled diamonds show expected compositions of the residual liquid at atmospheric pressure after adiabatic decompressional boiling of water fed by reservoirs at $300{ }^{\circ} \mathrm{C}, 325^{\circ} \mathrm{C}$ and $350{ }^{\circ} \mathrm{C}$. For computational purposes, the isotopic composition and $\mathrm{Cl}$ concentration of the water in the deep reservoir before boiling were assumed to be similar to that of the condensed water-steam mixture discharged from the Y-12 drill hole. The above two figures show that the isotopic compositions and $\mathrm{Cl}$ concentrations in the waters discharged by Double Bulger Geyser 11 and 16 days after the start of the annual disturbance cannot be explained by a simple adiabatic decompressional model with singlestep steam loss at atmospheric pressure. The isotopic changes accompanying single-step steam loss at atmospheric pressure were calculated using methods outlined in Truesdell and others (1977). Figures 16 and 17 are similar plots of $\delta \mathrm{D}$ and $\delta^{18} \mathrm{O}$ respectively versus $\mathrm{SO}_{4}$. The $\mathrm{Cl}$ and $\mathrm{SO}_{4}$ versus isotopic composition plots all show widely ranging anionic concentrations while the isotopic compositions show relatively little variation. These observations preclude evaporation at atmospheric pressure of standing water in a non-discharging pool as a way to explain the high concentration of $\mathrm{Cl}$ that was obtained after the start of the annual disturbance because that process would produce residual water that becomes progressively heavier as $\mathrm{Cl}$ and $\mathrm{SO}_{4}$ concentrations increase. 
One way to explain the data would be by a refluxing of some of the cooled and relatively dense boiled water back underground where it would again be heated to high temperature. This would occur during the non-discharging period just after the annual disturbance, when the water level in the vent was too low to sample. The previously boiled water, which had counterflowed downward, then undergoes additional decompressional boiling during subsequent upflow. In this model, the refluxed water must be re-heated to greater than $220{ }^{\circ} \mathrm{C}$ in order to minimize the partitioning of lighter isotopes into the vapor phase during subsequent "reboiling". Note that above 220 ${ }^{\circ} \mathrm{C}$, boiling causes the residual liquid water to become lighter in $\delta \mathrm{D}$ and only slightly heavier in $\delta^{18} \mathrm{O}$ (Truesdell and others, 1977).

Another way to attain the anomalously high concentrations of non-volatile dissolved constituents, and the isotopically heavy water, would be by non-adiabatic evaporation utilizing excess heat in the reservoir rock. For example, if the discharge up the main channel of flow occurred at a faster rate than fluid could migrate into that relatively open channel from the surrounding rock, there would have been a drop in fluid pressure at all depths within, and immediately adjacent to, the main channel of upflow. This would result in boiling-point temperatures in the neutral-chloride and acid-chloride-sulfate reservoirs becoming less than the prevailing reservoir temperatures. Boiling of water "in place" would then occur in the reservoirs, producing steam in excess of that obtained by adiabatic decompressional boiling, until rock temperatures declined to a point where rock temperature-fluid pressure conditions were again compatible with a new, adiabatic "boiling-point" curve.

According to the above models, Double Bulger Geyser's waters should have become isotopically heavier in $\delta^{18} \mathrm{O}$, and perhaps lighter in $\delta \mathrm{D}$ (if boiled in place above 220 ${ }^{\circ} \mathrm{C}$ ), as the $\mathrm{Cl}$ concentration increased. However, the first sample taken after the start of the annual disturbance was lighter in $\delta^{18} \mathrm{O}$, but heavier in $\delta \mathrm{D}$ relative to the preceding sample (Fig. 5d). But, it was not lighter in $\delta^{18} \mathrm{O}$ relative to the composition of Y-12 water (Fig. 15). We suggest that soon after the start of the annual disturbance the main source of the discharged water shifted slightly to produce fluid isotopically more closely related to Y-12 water. Subsequently, as subsurface pressures declined further, a $\mathrm{SO} 4$-rich water with a still different isotopic composition began to enter the discharge channel and mix in various proportions with the Cl-rich water (Fig. 18). We suspect that $\mathrm{SO} 4$-rich water enters the channel of upflow at a shallower depth than the $\mathrm{Cl}$-rich water entry.

On a diagram showing $\delta^{18} \mathrm{O}$ versus $\delta \mathrm{D}$ for all Norris waters, Double Bulger Geyser's waters, like Cistern Spring's waters, plot with the isotopically heavier waters (Fig. 12d). However, most (but not all) of Double Bulger Geyser's waters plot along the right side of the data cluster, while most (but not all) of Cistern Spring's waters plot toward the left side of the data cluster (Fig. 12c).

On a plot of $\mathrm{Cl}$ versus $\mathrm{SO}_{4}$, most waters collected from Double Bulger Geyser before the start of the annual disturbance fall along line B, which is radial from the origin, and which passes slightly above the Y-12 water data point (Fig. 18). However, the first two samples of water collected from Double Bulger Geyser have the lowest $\mathrm{SO}_{4}$ concentrations and plot close to line $\mathrm{A}$, which passes through the $\mathrm{Y}-12$ water data point. We note that the two data points that lie closest to line A also have the lightest $\delta \mathrm{D}$ values of any of the waters collected from Double Bulger Geyser, and also are among the three lightest in $\delta^{18} \mathrm{O}$ (Table 1). The only Double Bulger Geyser sample that is lighter in $\delta^{18} \mathrm{O}$ was the first sample collected after the start of the disturbance (Table 1 and Fig. 18). Thereafter, the $\delta^{18} \mathrm{O}$ of waters sampled from Double Bulger Geyser became progressively heavier as $\mathrm{SO}_{4}$ increased (Fig. 18). For comparison, $\mathrm{Cl}-\mathrm{SO} 4$ relations for waters from Cistern Spring and Porkchop Geyser also are shown in Figure 18. 
In striking contrast to the Double Bulger Geyser waters, variations in composition of Cistern Spring waters in the summer of 1995 lie along a single mixing trend with one endmember water having about $550 \mathrm{ppm} \mathrm{Cl}$ and $60 \mathrm{ppm} \mathrm{SO} 4$, and the other about $350 \mathrm{ppm} \mathrm{Cl}$ and 110 ppm SO4 (Fig. 18). There is no sign in the Cistern Spring waters of the evaporative concentration of non-volatile components that is exhibited by Double Bulger Geyser waters. On the other hand, most of the compositional variations in the Porkchop Geyser waters seem to be related to differences in the degree of vapor or steam loss from water that is compositionally similar to Y-12 water (the data points plot near line A in Fig. 18). However, there is no indication in the Porkchop Geyser waters of the high degree of high-temperature evaporation that appears to be occurring in the Double Bulger Geyser waters.

Porkchop Geyser waters exhibited a small increase in temperature and $\mathrm{Cl} / \mathrm{SO}_{4}$, a small decrease in $\mathrm{Na} / \mathrm{K}$, and a significant change in isotopic composition $\left(\delta \mathrm{D}\right.$ and $\delta^{18} \mathrm{O}$ became lighter) leading up to the annual disturbance (Fig. 6). After the disturbance there was a decrease in $\mathrm{Cl} / \mathrm{SO}_{4}$ and $\mathrm{pH}$, indicating that a small increase in an acidsulfate component was being incorporated into the discharge. The water also became isotopically heavier. At the same time the $\mathrm{Cl}$ concentration and $\mathrm{Na} / \mathrm{K}$ ratio increased, and discharge temperature decreased. The increase in $\mathrm{Cl}$ concentration and trend toward an isotopically heavier water after the start of the annual disturbance were probably mainly the result of a significant decrease in the rate of discharge. The slower rate of discharge allowed evaporation from the surface of the pool to affect water compositions. However, on a graph of $\delta^{18} \mathrm{O}$ versus $\delta \mathrm{D}$ the Porkchop Geyser waters show only about a $2 \%$ o range in $\delta^{18} \mathrm{O}$ and about an $8 \%$ range in $\delta \mathrm{D}$ (Fig. 19a), suggesting that atmospheric evaporation effects were not extreme.

Previously, Fournier and others (1991) proposed a model in which two reservoirs of alkaline-chloride water at different temperatures contribute water to Porkchop Geyser 's discharge. A decrease in $\mathrm{Na} / \mathrm{K}$ and increase in the enthalpy of the discharged water-steam mixture over a span of several years resulted from drawing a larger proportion of water from the deeper and hotter reservoir. Our 1995 data do not show the extreme variations in $\mathrm{Na} / \mathrm{K}$ reported by Fournier and others (1991) (Fig. 20). Apparently most of the water discharged by Porkchop Geyser in the summer of 1995 came from the deeper and hotter reservoir, with the proportion of deeper and hotter water becoming even larger (more K-rich water) leading up to the annual disturbance. After the annual disturbance the proportion of the deep component again decreased slightly.

"Wistful" Geyser showed little chemical or isotopic variation leading up the annual disturbance (Fig. 7). On the day of the disturbance there was an immediate drop in $\mathrm{pH}$ and $\mathrm{Cl} / \mathrm{SO}_{4}$ (Figs.7a and 7c).

continued to decrease and $\mathrm{SO}_{4}$ to increase for another 10 days, reaching respective minima and maxima on day 220 (Fig. 7b). By day 240 the concentration of $\mathrm{Cl}$ was larger, and the $\mathrm{Cl} / \mathrm{SO}_{4}$ was about the same as prior to the start of the annual disturbance. The $\mathrm{pH}$ change was as expected, generally decreasing in proportion with increasing sulfate (Figs. $7 \mathrm{a}$ and $7 \mathrm{~b}$ ). As was the case for Cistern Spring waters, in the "Wistful" Geyser waters both $\delta \mathrm{D}$ and $\delta^{18} \mathrm{O}$ became heavier as $\mathrm{Cl}$ decreased and $\mathrm{SO}_{4}$ increased (compare Fig. 7d with 7b). On the other hand, the $\mathrm{Na} / \mathrm{K}$ data showed little variation except for two anomalously low values on days 218 and 220 that also had the highest $\mathrm{SO}_{4}$ values (compare Fig. 7c with 7b).

Isotopically, "Wistful" Geyser waters became heavier in both $\delta \mathrm{D}$ and $\delta^{18} \mathrm{O}$ as $\mathrm{Cl} / \mathrm{SO}_{4}$ decreased (Figs. $7 \mathrm{c}$ and $7 \mathrm{~d}$ ). On a diagram showing $\delta^{18} \mathrm{O}$ versus $\delta \mathrm{D}$ for all Norris waters, "Wistful" waters exhibit almost the full range in isotopic compositions found in these waters (Fig. 19b). Prior to the start of the annual disturbance all the data plot with the isotopically lighter waters (Fig. $19 \mathrm{~b})$. In contrast, during the disturbance and for a few days thereafter, "Wistful" waters plot with the isotopically heavier waters, generally trending toward the isotopic composition of Vermilion Spring, a typical 
low-chloride, acid-sulfate, steam-heated, non-overflowing pool. Like the results for Double Bulger Geyser, the data points for "Wistful" Geyser plot at the right side of the data cluster. There is a general mixing trend that extends from the Y-12 composition toward an isotopically heavy acid-chloridesulfate water.

The response of "Carnegie" Spring water to the annual disturbance was very slight. There was a general trend of increasing temperature, $\mathrm{Cl}$, and $\mathrm{Cl} / \mathrm{SO}_{4}$ prior to the start of the disturbance (Figs. 8a, 8b and $8 \mathrm{c}$ ). These trends reversed immediately after the start of the disturbance. The relatively large variations in $\mathrm{Na} / \mathrm{K}$ ratios (Fig. 8c) are more apparent than real because the "Carnegie" Spring waters contain relatively little K. Therefore, small analytical differences of less than $1 \mathrm{ppm}$ (within the analytical uncertainty) result in relatively large differences in $\mathrm{Na} / \mathrm{K}$. Compared to predisturbance values, $\delta \mathrm{D}$ became slightly lighter after the disturbance, while $\delta^{18} \mathrm{O}$ became slightly heavier.

The "Carnegie" Spring waters have $\delta \mathrm{D}$ values close to that of the local meteoric water, and $\delta^{18} \mathrm{O}$ values about $1.5 \%$ o heavier than Y-12 water (Fig. 19c). Even though the "Carnegie" waters apparently issue from a relatively low-temperature reservoir at about $190^{\circ} \mathrm{C}$ (Table 2 and Fig. 11) they appear to have attained isotopic as well as chemical equilibration with the reservoir rock. However, the $\delta \mathrm{D}$ values close to that of the local meteoric water may be coincidental. Isotopic exchange with rock may have occurred mainly in a deeper and hotter reservoir before the water moved up into the shallower and cooler $190^{\circ} \mathrm{C}$ reservoir, where chemical, but not isotopic, re-equilibration occurred.

Perpetual Spouter waters behaved very similarly to the "Carnegie" Spring waters in that there was very little isotopic and chemical response to the annual disturbance. Relative to the pre-disturbance composition, $\delta \mathrm{D}$ recovered to slightly lighter values after the disturbance while $\delta^{18} \mathrm{O}$ remained nearly constant. Like the "Carnegie" Spring waters,
Perpetual Spouter waters have $\delta \mathrm{D}$ values close to those of the local meteoric water, and $\delta^{18} \mathrm{O}$ values about $1.5 \%$ o heavier than $\mathrm{Y}-12$ water (Fig. 19d). $\mathrm{Na} / \mathrm{K}$ and $\mathrm{Cl} / \mathrm{SO}_{4}$ variations probably reflect the analytical uncertainty in the measurements.

Over the course of the monitoring period Beryl Spring showed minor chemical and $\delta^{18} \mathrm{O}$ variations, but significant $\delta \mathrm{D}$ changes both before and after the disturbance (Fig. 10). However, like "Carnegie" Spring waters, Beryl Spring waters issue from a relatively low temperature reservoir (discussed above). This reservoir is probably relatively shallow and may not be sensitive to changes that trigger annual disturbance responses in the deep, hightemperature reservoirs beneath Norris Geyser Basin.

\section{TRIGGERING OF THE ANNUAL DISTURBANCE}

Fournier and others (1986) noted that several factors may be important in triggering the annual disturbance, including self-sealing by mineral deposition, clogging of channels by clay suspended in flowing waters, large geyser eruptions, seasonal changes in water table, deformation and fracturing induced by tectonic forces, and hydrofracturing. Of these, for most years seasonal variations in fluid pressure within the hydrothermal system are probably most important. Fournier (1983) pointed out that fluid pressures measured at the bottoms of shut-in wells drilled in thermal areas of YNP (White and others, 1975) generally are close to the pressures that would be exerted by overlying columns of cold water. This strongly suggests that there are relatively open hydraulic connections between the hydrothermal systems and the surrounding low-temperature groundwater systems. Accordingly, a possible explanation of the annual disturbance involves changes in reservoir pressure brought about by changes in the potentiometric surfaces of the regional cold water systems.

Temperature-depth curves in the central part of the hydrothermal system, where upward convective flow rates are greatest, come to define boiling-point curves 
appropriate for the fluid pressure profile. While fluid pressures within the hydrothermal "plumbing system" remain high (controlled by the cold-water system adjacent to the Norris hydrothermal system), waters in shallower, relatively low-pressure reservoirs are essentially held in check (unable to enter the channels of upflow and mix with the waters of deeper origin) because there is no pressure gradient to drive this entry. However, this situation is very unstable because a drop in pressure in the cold-water part of the system results in a drop in pressure in the hydraulically interconnected hot-water part of the system. In turn, this decrease in pressure requires that boiling temperatures at given depths decrease. But, rock temperatures do not decrease as rapidly as does the boiling-point curve. Liquid water vigorously flashes to steam (non-adiabatic evaporation at high pressure), energized by the heat stored in rock. The boiling "in place" and temporary increase in pressure within relatively shallow, acid-water reservoirs (rich in clay minerals) cause "muddy" water and steam to be ejected from these reservoirs into the main channels of upflow. The annual disturbance is initiated. The immediate, but temporary upward surge in pressure at the top of the system is followed shortly thereafter by a decline in pressure deeper in the system. This is because water from the deep reservoirs does not enter the channels of upflow at as fast a rate as water is propelled upward by expansion of "excess" steam, and because the increased proportion of steam to water lightens the "load" exerted by the overlying column of fluid. Where temperatures in shallow reservoirs are less than the prevailing boiling temperature, the general decline in pressure within the hydrothermal system allows waters in these initially lower-pressure reservoirs to enter the main channels of upflow without violent steam propulsion. There they mix with waters ascending from the deeper reservoirs, producing the mixed waters seen in some Norris springs and geysers.

The annual disturbance generally does not occur in the spring of the year because then the water table (potentiometric surface) is generally high as a result of the melting of thick covers of snow. At this time fluid pressure at given depths, both outside and inside the hydrothermal system, is higher than average. This situation allows the boiling point curve to rise slightly, and there is a heating of rock adjacent to the main channels of convective upflow in the heart of the hydrothermal system. As the summer progresses, the water table drops slightly, the rate of recharge of cold water decreases, groundwater temperature adjacent to the hydrothermal system increases slightly, and the density of the pressure-controlling column of "cold" water decreases. The boiling-point within the hydrothermal system drops in response to these changes and, in some places, previously heated rock gives up that heat by causing excess evaporative boiling (flashing to steam) of ascending fluids, as discussed above.

Beneath Double Bulger, evaporative boiling is probably occurring simultaneously in the shallower acid-chloride-sulfate and the deeper neutral-chloride reservoirs as a result of a drop in fluid pressure along the flow path. Elsewhere, as at Cistern Spring and "Wistful" Geyser, the main effect of a slight drop in fluid pressure along the flow path seems to be to allow larger proportions of waters from shallower reservoirs (the acidchloride-sulfate waters) to enter the channels of upflow and mix with the waters of deeper origin.

Annual disturbance phenomena may not occur in other geyser basins in YNP because the thermal waters in those basins are fed by shallower, lower-temperature reservoirs (180-215 ${ }^{\circ} \mathrm{C}$ at Lower and Upper Geyser Basins compared to $270-310{ }^{\circ} \mathrm{C}$ at Norris according to Fournier and others (1976) and Fournier (1989). It is also possible that annual disturbance phenomena do occur in other Geyser Basins, but have not been recognized because widespread shallow reservoirs of acid waters are not present in those basins to furnish the clay which makes hot spring and geyser waters murky at Norris Geyser Basin, heralding the onset of the disturbance there.

\section{SUMMARY AND CONCLUSIONS}

At the time of the annual disturbance there is widespread subsurface mixing of shallow, acid-chloride-sulfate water (reservoir temperature probably in the range 
about 180-220 $\left.{ }^{\circ} \mathrm{C}\right)$ with near-neutral, chloride-rich water ascending from highertemperature $\left(270{ }^{\circ} \mathrm{C}\right.$ to $\left.>300{ }^{\circ} \mathrm{C}\right)$, and presumably deeper, reservoirs beneath Norris Geyser Basin. In contrast, hot springs that discharge near-neutral, chloride-rich waters that have equilibrated with rock in reservoirs where temperatures are $250{ }^{\circ} \mathrm{C}$ or less show little chemical response to the annual disturbance. Acid-sulfate-chloride water, similar in composition to waters discharged in Porcelain Basin and 100 Spring Plain, underlies much of the Back Basin, but is discharged there only after mixing with the neutral-chloride water. Generally, this occurs only for short periods of time after annual disturbances.

The large volume of acid-chloride-sulfate water discharged by Echinus Geyser in the Back Basin is distinctly different chemically and isotopically compared with the Porcelain Basin and 100 Spring Plain acid-chloridesulfate waters (Figs. 14-17). The low chloride and isotopically relatively light Echinus Geyser-type waters do not appear to be mixing in significant amounts with the neutral-chloride waters in the Back Basin.

In contrast with the acid-sulfate-chloride waters discharged by Echinus Geyser, most of the acid-chloride-sulfate waters at Norris are isotopically relatively heavy in both $\delta \mathrm{D}$ and $\delta^{18} \mathrm{O}$ (Figs. 14-18). To date, all of the waters collected from non-discharging, steam-heated, acid-sulfate pools at Norris and elsewhere in YNP have been found to be isotopically heavy (for example, the Vermilion Spring pool shown in Figs. 12 and 19). Some of this type of water is likely to percolate into the ground and mix with other subsurface waters.

The extremely high concentrations of $\mathrm{Cl}$ and $\mathrm{SO}_{4}$ in waters collected from Double Bulger Geyser after the start of the 1995 annual disturbance are probably the result of excess boiling (more steam loss than can be accounted for by adiabatic decompressional boiling of a "once-through" fluid). Excess boiling may have occurred as a result of counter flow of previously boiled fluid back underground where it was re-heated to over $220{ }^{\circ} \mathrm{C}$. This water then boiled adiabatically a second time during subsequent convective upflow; the cycle may have been repeated more than once. Alternatively, and more likely, a drop in fluid pressure all along the channel of upflow resulted in excess boiling of water in neutral-chloride and acid-chloridesulfate reservoirs that supply water to Double Bulger Geyser.

Triggering of the annual disturbance probably is caused mainly by annual changes in elevation of the potentiometric surface of the cold-water system that surrounds the Norris hydrothermal system, although seismicity may be important sometimes. In the spring the water table is high and rate of downward percolation of cold water adjacent to the Norris hydrothermal system is greatest. At this time fluid pressures within the interconnected cold-and hot-water systems are highest. While high fluid pressure prevails along paths or channels of upward hydrothermal convective fluid flow, the flow of acid-chloride-sulfate waters from relatively shallow, low-pressure reservoirs into the main channels of upflow is prevented because there is no pressure gradient driving that entry. Generally, by the end of the summer months, there is a decrease in the elevation of the local potentiometric surface (the water table) sufficient to result in a decrease in fluid pressure within that hydrothermal system. In reservoirs at various depths excess evaporative boiling is induced which initially produces an upward pressure surge at shallow depths, followed by a rapid decline in pressure deeper in the hydrothermal system. The drop in pressure allows acid-chloride-sulfate waters to enter the channels of upflow and mix with the neutral-chloride waters of deeper origin.

Annual disturbance phenomena that are easily recognized at Norris Geyser Basin may not be easily recognized elsewhere in Yellowstone National Park because (1) the neutral-chloride waters that are fed from relatively shallow, and lower-temperature reservoirs in other geyser basins may not react as vigorously in their steam production as do the waters in the very high-temperature Norris reservoirs in response to small pressure changes outside of the hydrothermal system, and (2) the clay that makes hot spring and geyser waters become turbid at Norris, heralding the start of the disturbance, comes from acid altered rocks that are widely 
distributed at intermediate depths at Norris, and that are rare in other geyser basins.

\section{Acknowledgments}

We wish to thank the U.S. National Park Service for allowing collection of the samples. We also wish to thank Anne E. Gartner of the U.S.G.S. for her great help in keeping track of the samples and expediting their distribution to the laboratories that carried out the chemical and isotopic analyses.

\section{REFERENCES}

Allen, E.T. and Day, A.L., 1935, Hot springs of the Yellowstone National Park: Carnegie Institution of Washington Publication 466, $525 \mathrm{p}$.

Arnórsson, S., 1983, Chemical equilibria in Icelandic geothermal systems Implications for chemical geothermometry investigations: Geothermics, vol. 12, p. 119-128.

Fenner, C.N., 1936, Bore-hole investigation in Yellowstone Park: Journal of Geology, vol. 44, p. 225-315.

Fournier, R.O., 1979, A revised equation for the $\mathrm{Na} / \mathrm{K}$ geothermometer. Geothermal. Resources Council Transactions, vol. 3, p. 221-224.

Fournier, R.O., 1981, Application of water geochemistry to geothermal exploration and reservoir engineering, in Ryback, L., and Muffler, L. J. P., eds., Geothermal Systems: Principles and Case Histories: New York, Wiley, p. 109-143.

Fournier, R.O., 1983, Active hydrothermal systems as analogues of fossil systems, in The role of heat in the development of energy and mineral resources in the Northern Basin and Range province: Geothermal Resources Council Special Report No. 13, p. 263-284.

Fournier, R.O., 1985, The behavior of silica in hydrothermal solutions, in Berger, B.R., and Bethke, P.M., eds., Geology and geochemistry of epithermal systems: Reviews in Economic Geology, vol. 2, p. 45-61.

Fournier, R.O., 1989, Geochemistry and dynamics of the Yellowstone National Park hydrothermal system, Wyoming:
Annual Review of Earth and Planetary Sciences, vol. 17, p. 13-53.

Fournier, R.O., 1991, Water geothermometers applied to geothermal energy, Chapter 2 in D'Amore, Franco, coordinator, Application of Geochemistry in Geothermal Reservoir Development: Rome, Italy, UNITAR/UNDP Centre on Small Energy Resources, p. 37-69.

Fournier, R.O., Kennedy, B.M., Aoki, M., and Thompson, J.M., 1994, Correlation of gold in siliceous sinters with ${ }^{3} \mathrm{He} /{ }^{4} \mathrm{He}$ in hot spring waters of Yellowstone National Park: Geochimica et Cosmochimica Acta, vol. 58, p. 5401-5419.

Fournier, R.O., and Potter, R.W., II, 1982, A revised and expanded silica (quartz) geothermometer: Geothermal Resources Council Bull., vol. 11, no. 10, p. 3-12.

Fournier, R.O., and Rowe, J.J., 1966, Estimation of underground temperatures from the silica content of water from hot springs and wet-steam wells: American Journal of Science., vol. 264, p. 685-697.

Fournier, R.O., Thompson, J.M., Cunningham, C.G., and Hutchinson, R.A., 1991, Conditions leading to a recent small hydrothermal explosion at Yellowstone National Park: Geological Society of America Bulletin, vol. 103, p. 1114-1120.

Fournier, R.O., Thompson, J.M., and Hutchinson, R.A., 1986, Fluctuations in composition of Cistern Spring, Norris Geyser Basin, Yellowstone National Park, Wyoming_variable boiling and mixing 1962-1985: Extended Abstracts, Fifth International Symposium on Water-Rock Interaction, Reykjavík, Iceland, International Association of Geochemistry and Cosmochemistry, $\mathrm{p}$. 206-209.

Fournier R. O., Thompson J. M., and Hutchinson R. A., 1992, The geochemistry of hot spring waters at Norris Geyser Basin, Yellowstone National Park, USA, in Kharaka, Y. K., and Maest, A. S., eds., Proceedings of the 7th International Symposium. on Water-Rock Interactions, Rotterdam, 
Balkema, ISBN 905410 0753, vol. 2, p. 1289-1292.

Fournier, R.O., White, D.E., and Truesdell, A.H., 1976, Convective heat flow in Yellowstone National Park, in Proceedings, Second UN Symposium on the Development and Use of Geothermal Resources: Washington, D.C., U.S. Government Printing Office, vol. I, p. 731-739.

Giggenbach, W. F., 1988, Geothermal solute equilibria. Derivation of $\mathrm{Na}-\mathrm{K}$ $\mathrm{Mg}-\mathrm{Ca}$ geoindicators: Geochimica et Cosmochimica Acta, vol. 52, p. 2749-2765.

Gooch, F.A., and Whitfield, J.E., 1888, Analyses of waters of the Yellowstone National Park, with an account of the methods of analysis employed: U.S. Geological Survey Bulletin 47, 84 p.

Rowe, J.J., Fournier, R.O., and Morey, G.W., 1973, Chemical analyses of thermal waters in Yellowstone National Park, Wyoming, 1960-1965: U.S. Geological Survey Bulletin 1303, 31 p.

Thompson, J.M., and DeMonge, J. M., 1996, Chemical analyses of hot springs, pools, and geysers from Yellowstone National Park, Wyoming, and vicinity, 1980-1993: U.S. Geological Survey Open-File Report 96-68, 66 p.

Thompson, J.M., Presser, T.S., Barnes, R.B., and Bird, D.B., 1975, Chemical analyses of the waters of Yellowstone National Park, Wyoming, from 1965-1973: U.S. Geological Survey Open-File Report 75-25, 59 p.

Thompson, J.M., and Yadav, S., 1979. Chemical analyses of waters from geysers, hot springs and pools in Yellowstone National Park, Wyoming, from 1974-1978: U.S. Geological Survey Open-File Report 79-704, 49 p.

Truesdell, A. H., 1976, Summary of section III geochemical techniques in exploration, in Proceedings, Second UN Symposium on the Development and Use of Geothermal Resources: Washington, D.C., U.S. Gov. Printing Office, vol. I, p. liii-lxxxix.

Truesdell A. H., Nathenson M., and Rye, R.O, 1977, The effects of subsurface boiling and dilution on the isotopic compositions of Yellowstone thermal waters: Journal of Geophysical Research, vol. 82, p. 3694-3704.

Trujillo, P.E., Counce, D., Grigsby, C.O., Goff, F., and Shevenell, L., 1987, Chemical analysis and sampling techniques for geothermal fluids and gases at the Fenton Hill Laboratory: Los Alamos National Laboratory Publication LA-11006-MS, 84 p.

White, D.E., Fournier, R.O., Muffler, L.J.P., and Truesdell, A.H., 1975, Physical results of research drilling in thermal areas of Yellowstone National Park, Wyoming: U.S. Geological Survey Professional Paper 892, 70 p.

White, D.E., Hutchinson, R.A., and Keith, T.E.C., 1988, The geology and remarkable thermal activity of Norris Geyser Basin, Yellowstone National Park, Wyoming: U.S. Geological Survey Professional Paper 1456, 84 p. 


\section{Figure Captions}

Figure 1. Sketch map of Norris Geyser Basin, Yellowstone National Park, showing topographic features, locations of features that were monitored, U.S. Geological Survey drill holes Y-9 and Y-12, and other selected hot springs and geysers. Contours show equal altitude in feet.

Figure 2. Chemical and isotopic variations versus Julian day for Sulfur Dust Spring.

a) temperature and $\mathrm{pH}$ versus Julian day. b) $\mathrm{Cl}$ and $\mathrm{SO}_{4}$ versus Julian day.

c) $\mathrm{Na} / \mathrm{K}$ and $\mathrm{Cl} / \mathrm{SO}_{4}$ versus Julian day. d) $\delta \mathrm{D}$ and $\delta^{18} \mathrm{O}$ versus Julian day.

Figure 3. Chemical and isotopic variations versus Julian day for "Black" Spring.
a) temperature and $\mathrm{pH}$ versus Julian day. b) $\mathrm{Cl}$ and $\mathrm{SO}_{4}$ versus Julian day.
c) $\mathrm{Na} / \mathrm{K}$ and $\mathrm{Cl} / \mathrm{SO}_{4}$ versus Julian day. d) $\delta \mathrm{D}$ and $\delta^{18} \mathrm{O}$ versus Julian day.

Figure 4. Chemical and isotopic variations versus Julian day for Cistern Spring.
a) temperature and $\mathrm{pH}$ versus Julian day. b) $\mathrm{Cl}$ and $\mathrm{SO}_{4}$ versus Julian day.
c) $\mathrm{Na} / \mathrm{K}$ and $\mathrm{Cl} / \mathrm{SO}_{4}$ versus Julian day. d) $\delta \mathrm{D}$ and $\delta^{18} \mathrm{O}$ versus Julian day.

Figure 5. Chemical and isotopic variations versus Julian day for Double Bulger Geyser.
a) temperature and $\mathrm{pH}$ versus Julian day. b) $\mathrm{Cl}$ and $\mathrm{SO}_{4}$ versus Julian day.
c) $\mathrm{Na} / \mathrm{K}$ and $\mathrm{Cl} / \mathrm{SO}_{4}$ versus Julian day. d) $\delta \mathrm{D}$ and $\delta^{18} \mathrm{O}$ versus Julian day.

Figure 6. Chemical and isotopic variations versus Julian day for Porkchop Geyser.
a) temperature and $\mathrm{pH}$ versus Julian day. b) $\mathrm{Cl}$ and $\mathrm{SO}_{4}$ versus Julian day.
c) $\mathrm{Na} / \mathrm{K}$ and $\mathrm{Cl} / \mathrm{SO}_{4}$ versus Julian day. d) $\delta \mathrm{D}$ and $\delta^{18} \mathrm{O}$ versus Julian day.

Figure 7. Chemical and isotopic variations versus Julian day for "Wistful" Geyser.
a) temperature and $\mathrm{pH}$ versus Julian day. b) $\mathrm{Cl}$ and $\mathrm{SO}_{4}$ versus Julian day.
c) $\mathrm{Na} / \mathrm{K}$ and $\mathrm{Cl} / \mathrm{SO} 4$ versus Julian day. d) $\delta \mathrm{D}$ and $\delta^{18} \mathrm{O}$ versus Julian day.

Figure 8. Chemical and isotopic variations versus Julian day for "Carnegie" Spring. a) temperature and $\mathrm{pH}$ versus Julian day. b) $\mathrm{Cl}$ and $\mathrm{SO}_{4}$ versus Julian day. c) $\mathrm{Na} / \mathrm{K}$ and $\mathrm{Cl} / \mathrm{SO}_{4}$ versus Julian day. d) $\delta \mathrm{D}$ and $\delta^{18} \mathrm{O}$ versus Julian day. 
Figure 9. Chemical and isotopic variations versus Julian day for Perpetual Spouter.

a) temperature and $\mathrm{pH}$ versus Julian day. b) $\mathrm{Cl}$ and $\mathrm{SO}_{4}$ versus Julian day.

c) $\mathrm{Na} / \mathrm{K}$ and $\mathrm{Cl} / \mathrm{SO}_{4}$ versus Julian day. d) $\delta \mathrm{D}$ and $\delta^{18} \mathrm{O}$ versus Julian day.

Figure 10. Chemical and isotopic variations versus Julian day for Beryl Spring.

a) temperature and $\mathrm{pH}$ versus Julian day. b) $\mathrm{Cl}$ and $\mathrm{SO}_{4}$ versus Julian day.

c) $\mathrm{Na} / \mathrm{K}$ and $\mathrm{Cl} / \mathrm{SO}_{4}$ versus Julian day. d) $\delta \mathrm{D}$ and $\delta^{18} \mathrm{O}$ versus Julian day.

Figure 11. Temperatures of reservoirs estimated using the $\mathrm{Na} / \mathrm{K}$ geothermometer of Giggenbach (1988) compared with estimated reservoir temperatures using the silica (quartz) geothermometer of Fournier and Potter (1982). Circles plot at silica temperatures estimated assuming adiabatic cooling and x's plot at silica temperatures estimated assuming conductive cooling.

Figure 12. $\delta \mathrm{D}$ versus $\delta^{18} \mathrm{O}$ for all Norris waters compared with a) Sulfur Dust Spring waters, b) "Black" Spring waters, c) Cistern Spring waters, and d) Double Bulger Geyser waters.

Figure 13. Variations in $\mathrm{Cl}, \mathrm{Na}, \mathrm{K}, \mathrm{SO}_{4}$, and $\mathrm{Br}$ versus Julian day for Double Bulger Geyser waters.

Figure 14. $\delta \mathrm{D}$ and $\mathrm{Cl}$ relations in Double Bulger Geyser Sulfur Dust Spring, Echinus Geyser, and Y-12 waters compared with all other data for Norris waters. Diamonds show calculated compositions of Y-12 waters after adiabatic decompressional boiling from the indicated initial reservoir temperatures with single stage steam separation at atmospheric pressure.

Figure 15. $\delta^{18} \mathrm{O}$ and $\mathrm{Cl}$ relations in Double Bulger Geyser, Sulfur Dust Spring, Echinus Geyser, and Y-12 waters compared with all other data for Norris waters. Diamonds show calculated compositions of Y-12 waters after adiabatic decompressional boiling from the indicated initial reservoir temperatures with single stage steam separation at atmospheric pressure. 
Figure 16. $\delta \mathrm{D}$ and $\mathrm{SO}_{4}$ relations in Double Bulger Geyser, Sulfur Dust Spring, Echinus Geyser, and Y-12 waters compared with all other data for Norris waters.

Figure 17. $\delta^{18} \mathrm{O}$ and $\mathrm{SO}_{4}$ relations in Double Bulger Geyser, Sulfur Dust Spring, Echinus Geyser, and Y-12 waters compared with all other data for Norris waters.

Figure 18. $\mathrm{SO}_{4}$ versus $\mathrm{Cl}$ for Double Bulger Geyser , Cistern Spring, and Porkchop

Geyser waters. $\delta^{18} \mathrm{O}$ values are shown for selected waters. See text for discussion.

Figure $19 . \delta \mathrm{D}$ versus $\delta^{18} \mathrm{O}$ for all Norris waters compared with a) Porkchop Geyser waters, b) "Wistful" Geyser waters, c) "Carnegie" Spring waters, and d) Perpetual Spouter waters.

Figure 20. K versus Na for Porkchop Geyser waters. Waters collected prior to 1985 all plot below the dashed line.

Table 1. Results of chemical and isotopic analyses

Table 2. Estimated reservoir temperatures using silica and $\mathrm{Na} / \mathrm{K}$ geothermometers 


\section{Appendix 1 - Field notes}

June 11 (day 162) Double Bulger Geyser - Heavier than previous boils $\approx 2-3 \mathrm{ft}$

June 22 (day 173) Temperature probe on the Orion combination temperature-pH meter broke - Now using a different electronic thermometer made by Keithly. Must manually enter temperature to get an accurate $\mathrm{pH}$ reading.

June 23 (day 174) Sulfur Dust Spring- Surprised by higher $\mathrm{pH}$. Pipette slipped so the accuracy of the $10 \mathrm{ml}$ sample for silica analysis is off. Question the accuracy of the electronic thermometer now being used. Will check it against the new probe when it becomes available. The present probe seems to give slightly cooler readings than the previous probe.

There were new hydrothermal breakouts near Amethyst - continuous boils 3-4 ft. Ledge Spring boiling 2-3 ft.

June 30 (day 181) Ledge Spring is overflowing. Mudpots are active. Rock Springs are empty with steam discharge. Lots of new hot areas east of Sulfur Dust Spring at the Black and White Springs. Many new springs at old hydrothermal area west of Ragged Hills.

July 2 (day 183) Double Bulger Geyser water level is lower by a few inches, but splash seems higher.

Cistern Spring run-off seems more significant to the east - less to the west. 
July 15 (day 196) The $\mathrm{pH}$ probe broke. Must cool the water below $80^{\circ} \mathrm{C}$ to get a $\mathrm{pH}$ reading with a different probe. No $\mathrm{pH}$ readings were measured on this date.

July 21 (day 202) Sulfur Dust Spring temperature measured with the Keithly electronic thermometer used since June $23 \mathrm{rd}$ is $44.2^{\circ} \mathrm{C}$. For comparison, the Orion thermometer with maximum temperature limit of $80^{\circ} \mathrm{C}$ is $46.0^{\circ} \mathrm{C}$.

July 22 (day 203) Both temperature probes replaced. Now functioning with just the Orion equipment.

July 23 (day 204) Significant ground temperature increases between Double Bulger Geyser and the boardwalk, including the western side of the creek running past Porkchop Geyser . A new sink hole with "sizzling" water on the western side of the boardwalk directly across from Double Bulger Geyser . Ground steaming on both sides of the boardwalk beyond Bastille. Bastille still holding water. Pearl in constant eruption with overflow to the north, southeast, and southwest. Splashes reaching 1/2 way between its vent and the boardwalk. Southwest runoff extending under boardwalk towards Porkchop Geyser. Porkchop Geyser having periodic light boils with significant increase of runoff extending north into "second eruptor" and south flowing into the creek. 3 new sputtering vents upstream from the bridge over Tantalus Creek.

July 26 (day 207) Double Bulger Geyser down 1.0 -1.5 ft with eruptions clearing the rim 1-3 ft. Heavy runoff continues around Pearl Geyser and Porkchop Geyser with more /new runoff flowing directly east from Porkchop. Yellow Funnel Spring's water level is down about 6" to 1'. New sink holes around Bastille on both sides of the boardwalk. Dabble erupting from a pool about $3 \mathrm{ft}$ in 
diameter. Hydrophane down 4" to 6" since Saturday (in 4 days). Acidic springs such as Son of Green Dragon, Orbe, "the Cousins", Blue Mud Spring don't seem to have any change (or have only slight change) in water level/activity.

July 27 (day 208) Cistern Spring's water has become very green - relatively light boils over the vent.

July 29 (day 210) The "annual disturbance" is clearly underway at Norris.

Sept. 9 (day 252) Double Bulger Geyser water level is up a few inches, but there is still no overflow from the system.

Sept. 10 (day 253) Double Bulger Geyser water level now down approximately 4" from rim - lower than last week.

Sept. 11 (day 254) Orange cyanobacteria mats redeveloping on the terraces. The entire basin has not yet returned to pre-disturbance activity. Cistern Spring's pH continues to slowly rise. Double Bulger Geyser still has low $\mathrm{pH}$ and less water in the system compared to pre-disturbance levels. The acidic springs from Crater to Son of Green Dragon still have lower water levels and turbulence. Yellow Mud still is having 3-4' boils. Yellow Funnel's water level has been increasing over the last week and is about 6" to 1' below the pre-disturbance level. Hydrophane and the surrounding area still has lower water levels. Vixen still erupts every 1-4 minutes. Bastille is still in constant eruption and Pearl has remained in a steam phase since the start of the "annual disturbance". 
Sept. 16 (Day 259) Cistern Spring has increased amounts of orange Cyanobacteria mats that are forming. Still, the majority of the previous mats are white. Double Bulger Geyser is erupting from a lower water level approximately 6" to 8" below the rim. Only light spray is periodically erupting from the unnamed geyser between Double Bulger Geyser and Bastille.

Sept. 21 (day 264) The unnamed geyser between Double Bulger Geyser and Bastille has no water erupting. The water level in Double Bulger Geyser has not changed significantly.

Sept. 26 (day 269) No water is visible in Double Bulger Geyser

Sept. 28 (day 271) the water level is again 6-8" below the rim of Double Bulger Geyser 


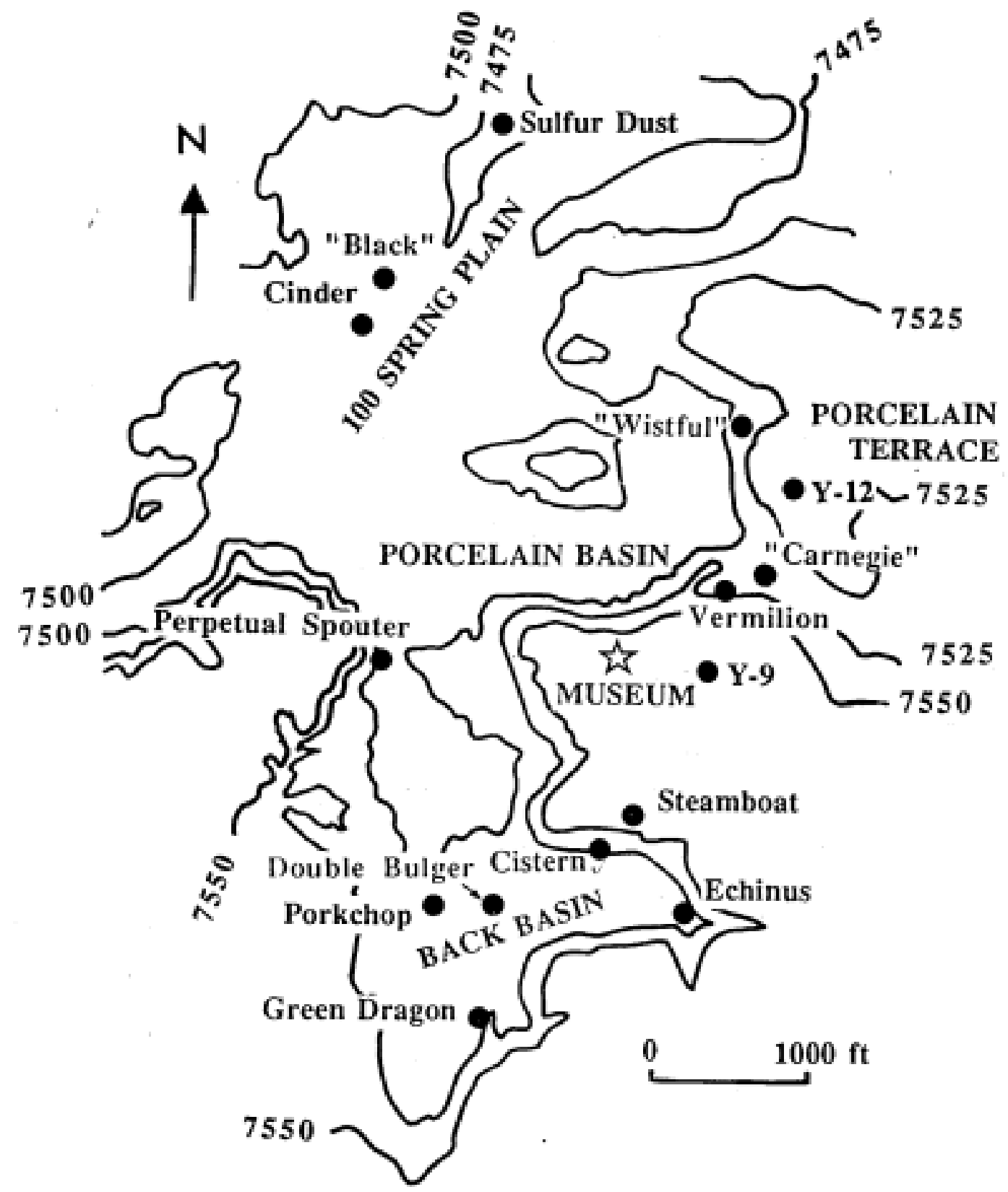

Figure 1 

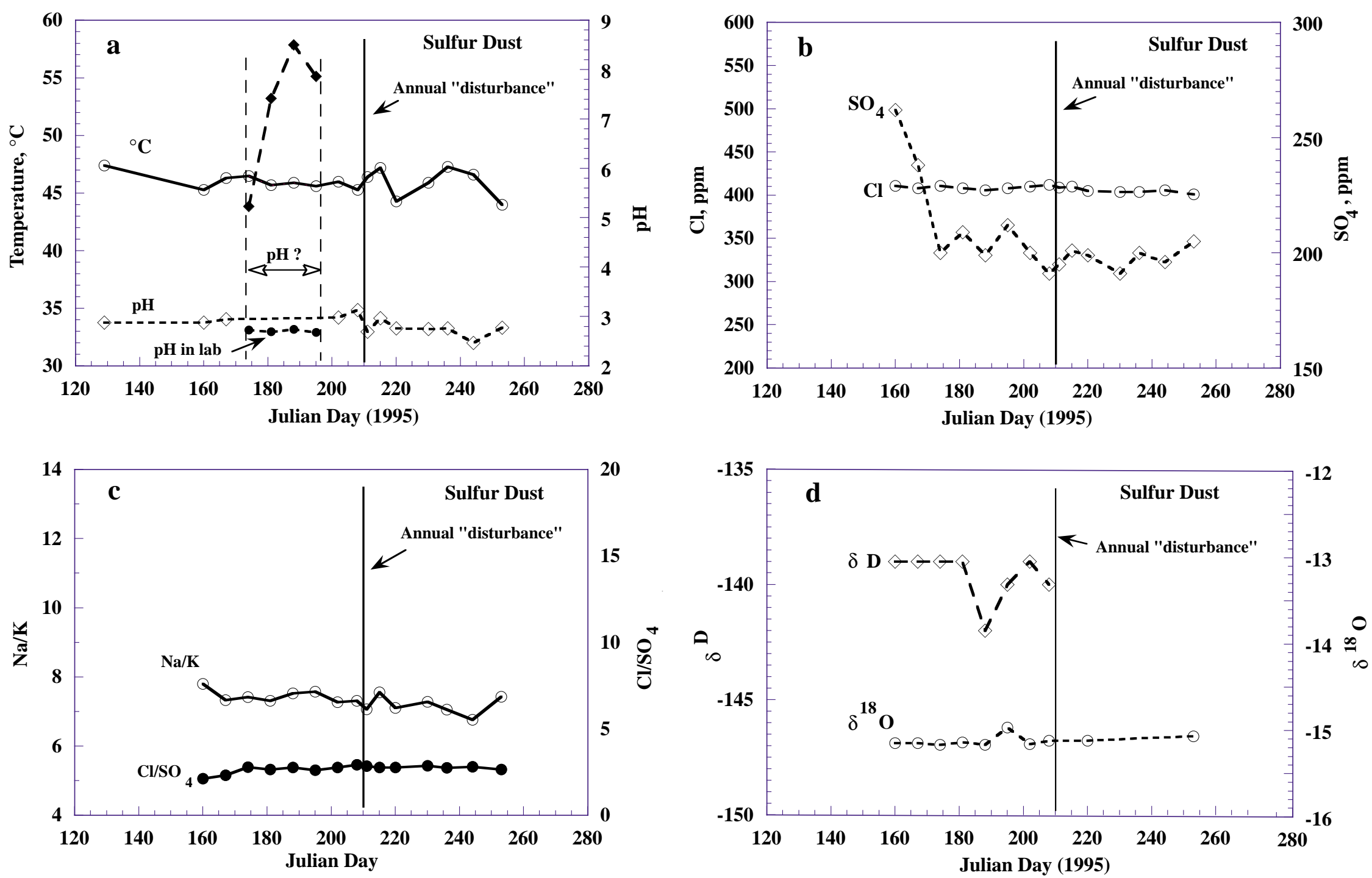

Figure 2 

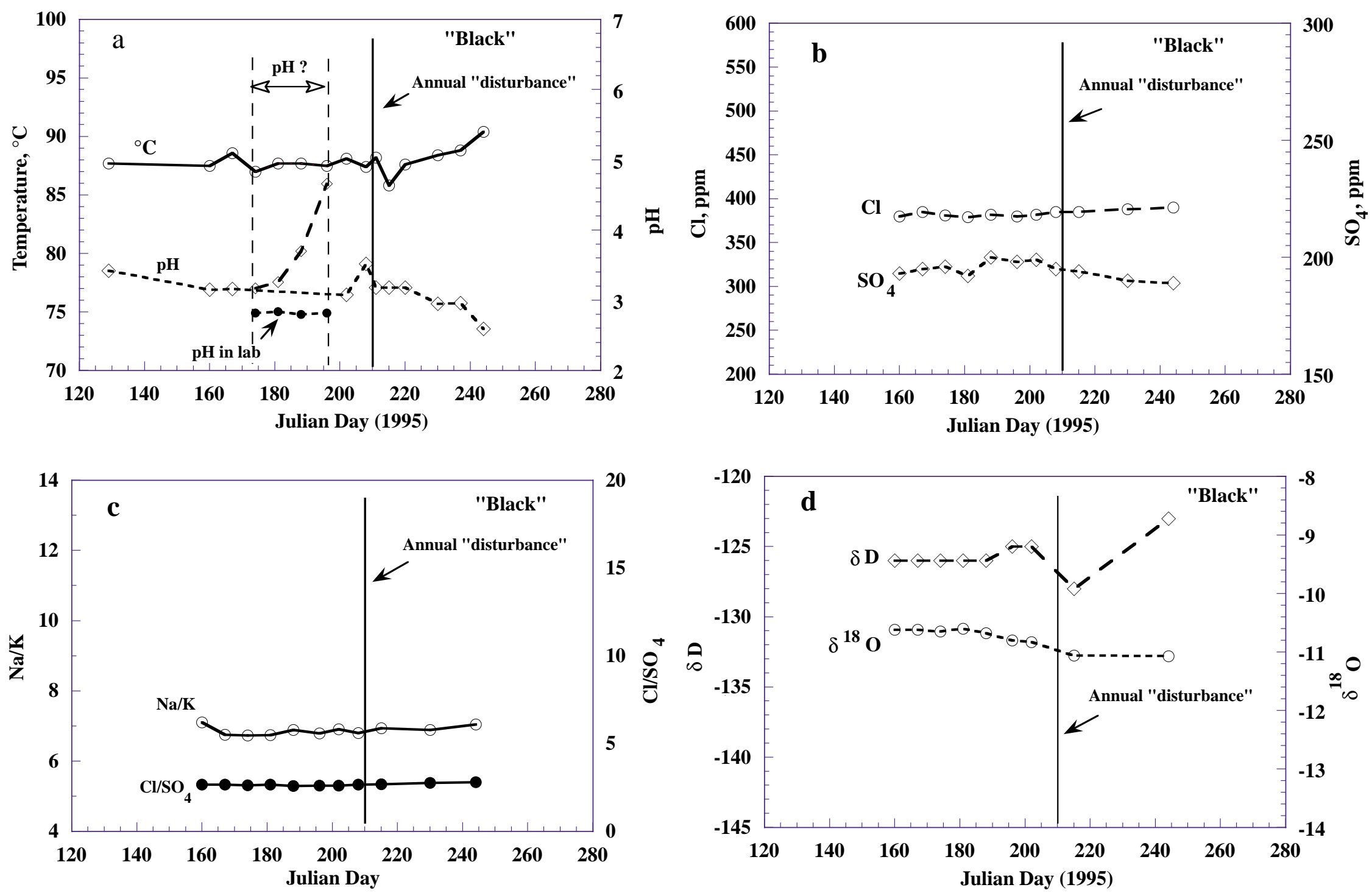

Figure 3 

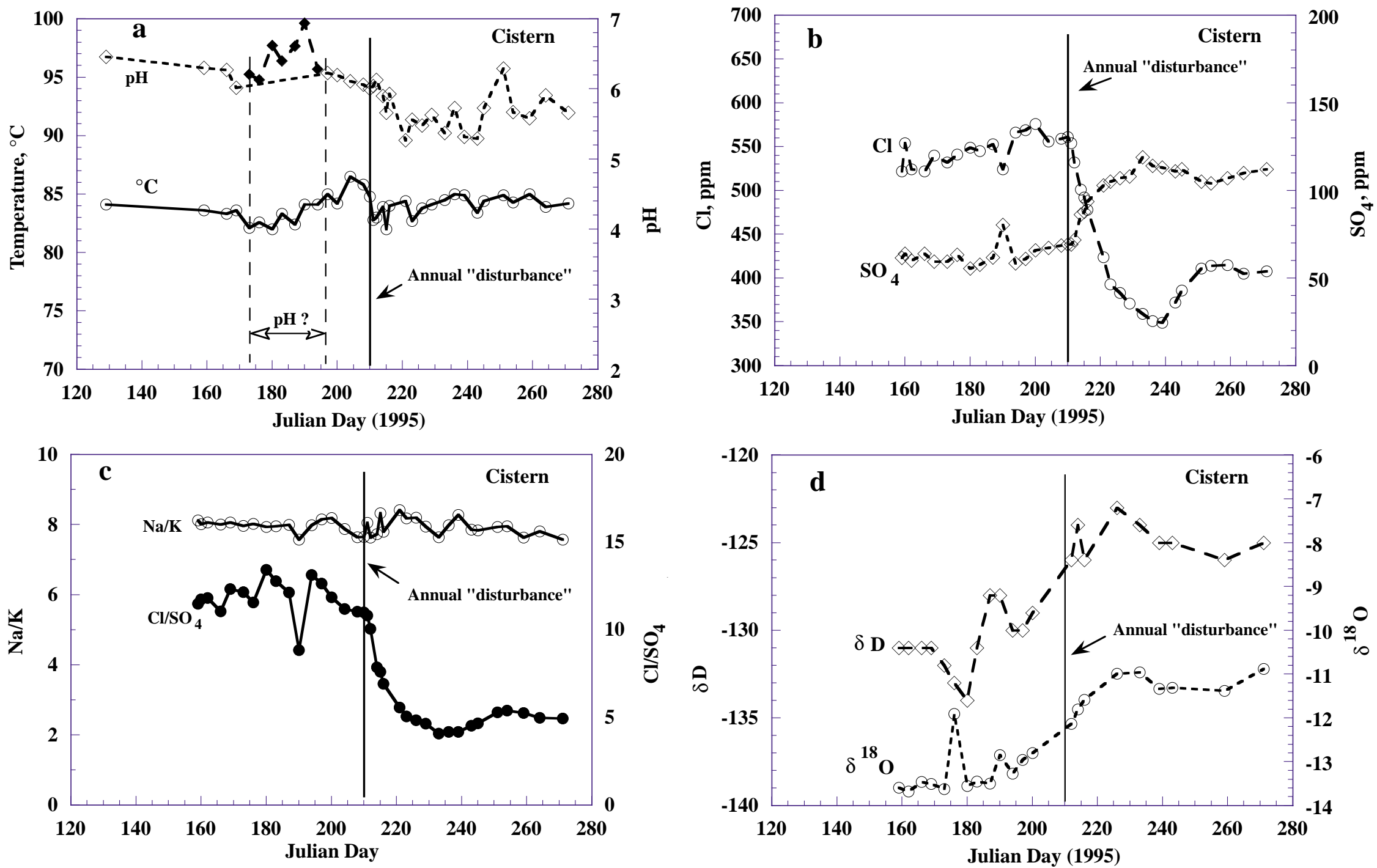

Figure 4 

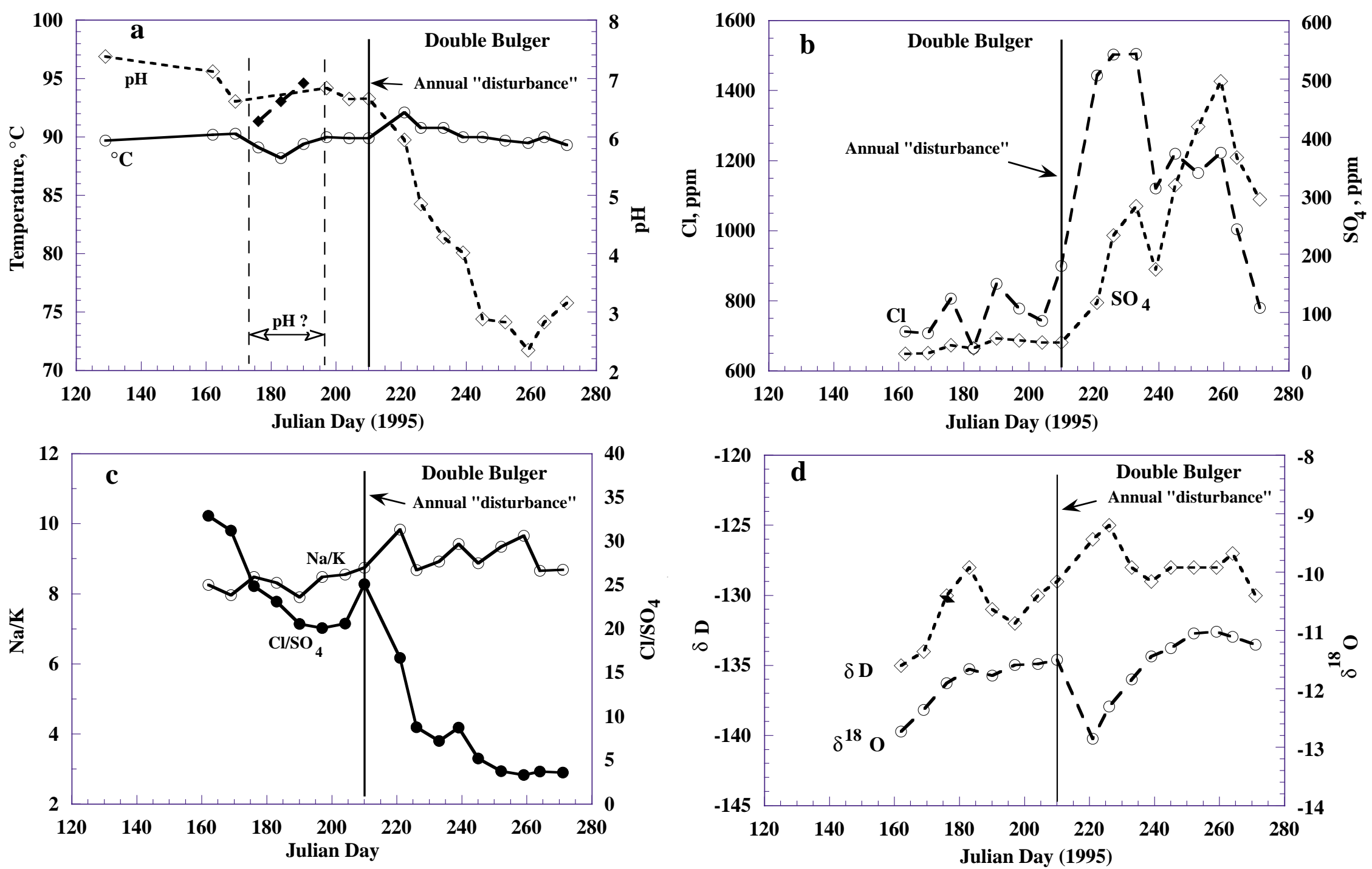

Figure 5 

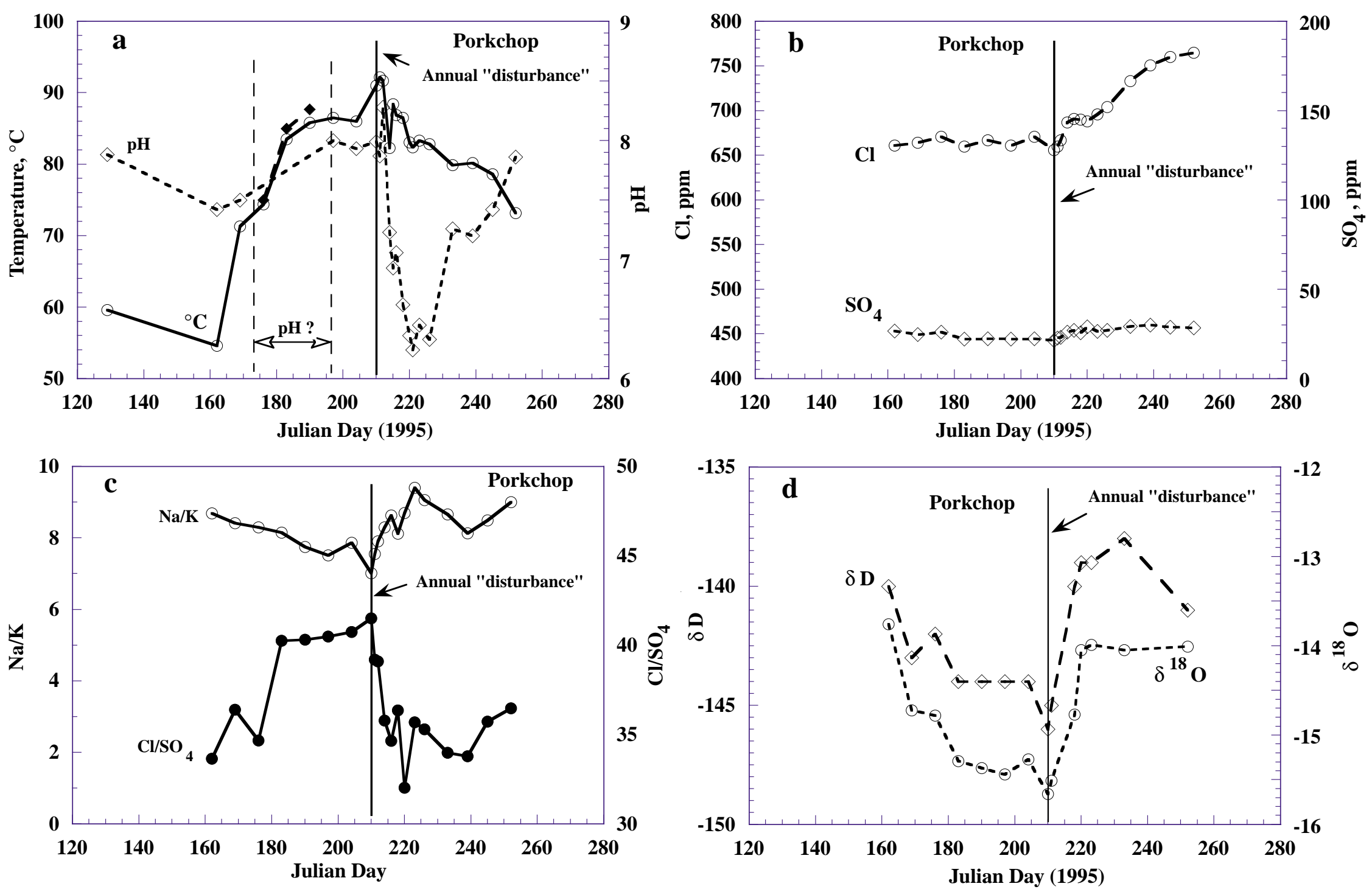

Figure 6 

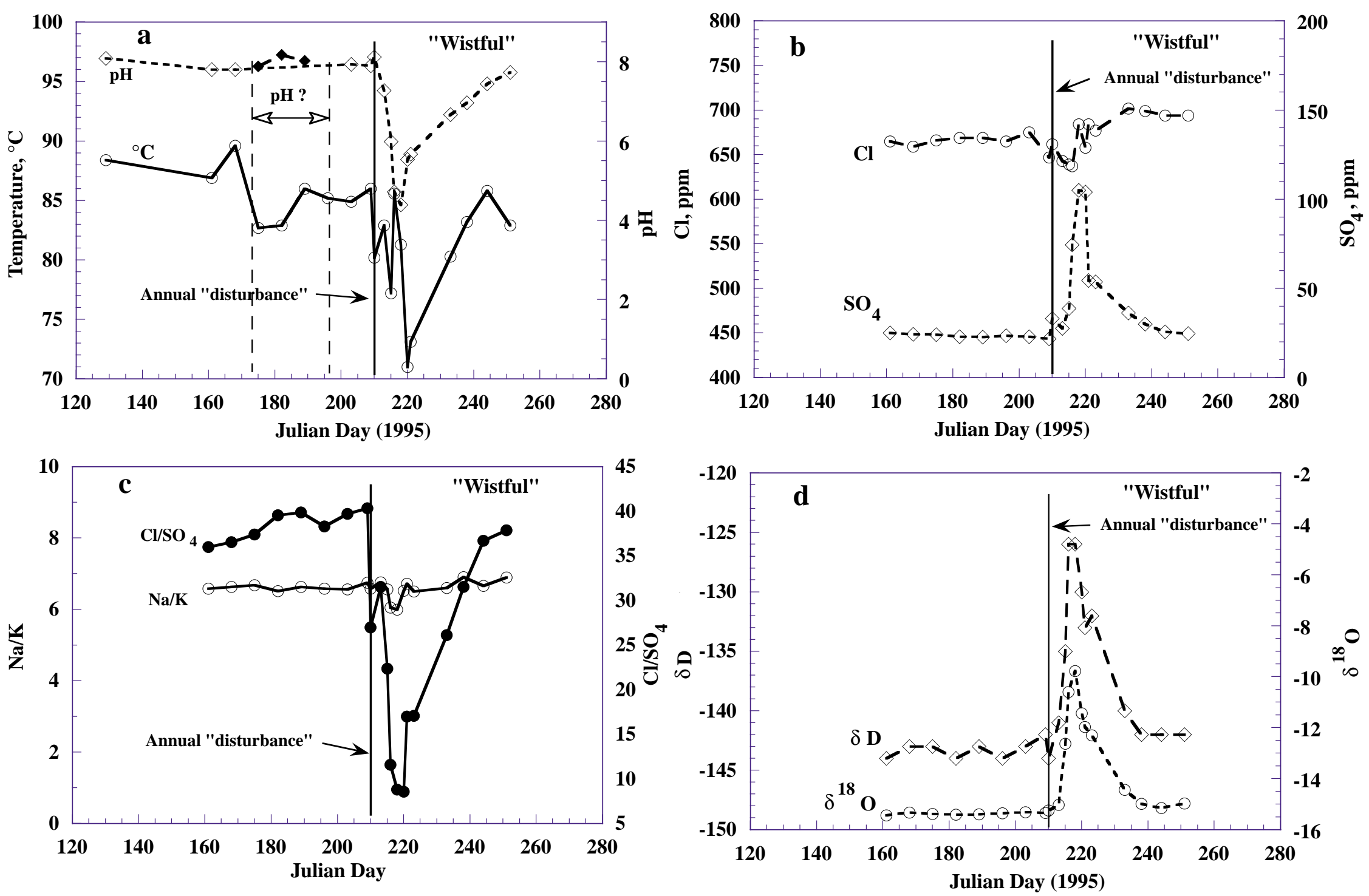

Figure 7 

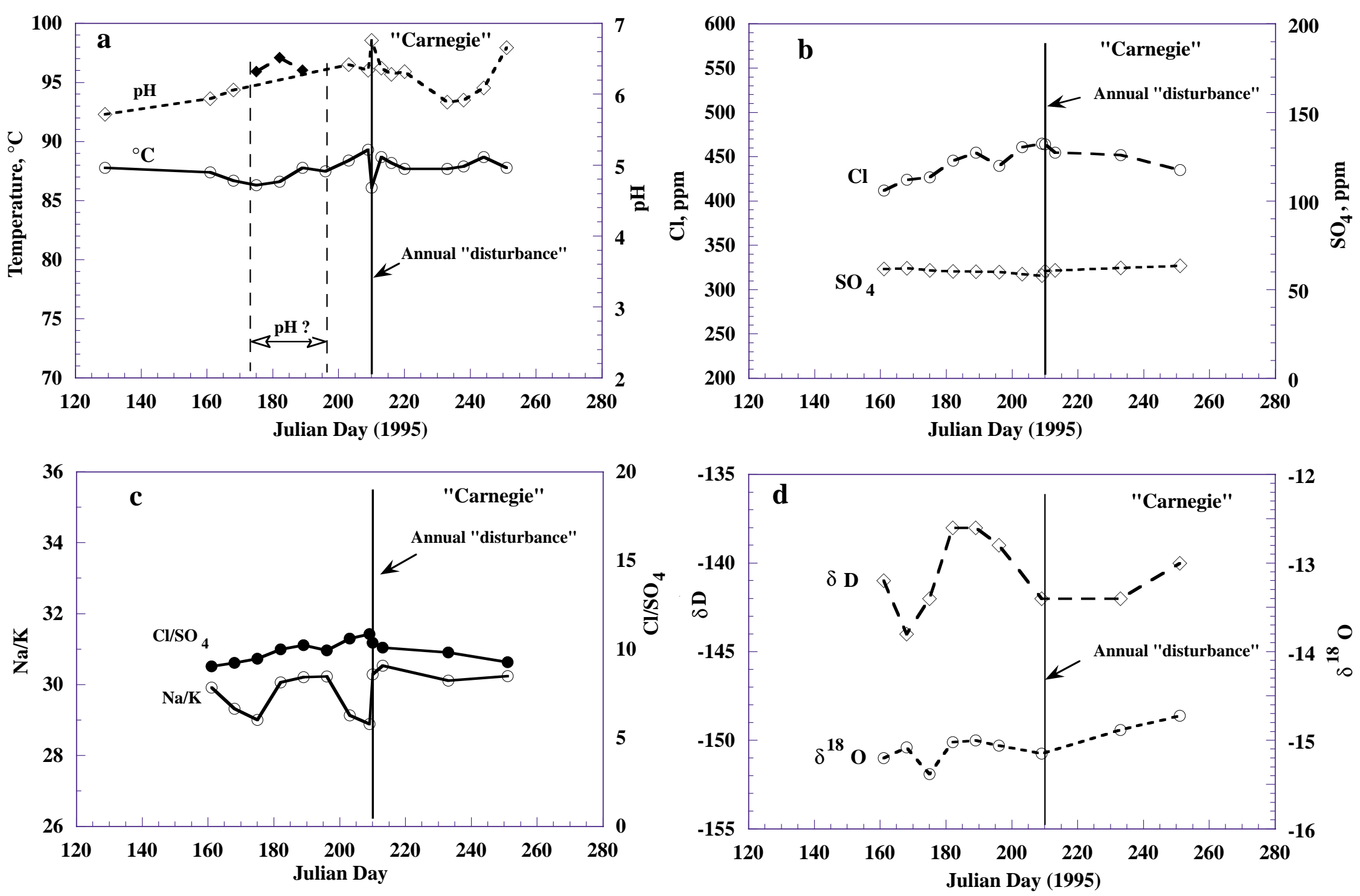

Figure 8 

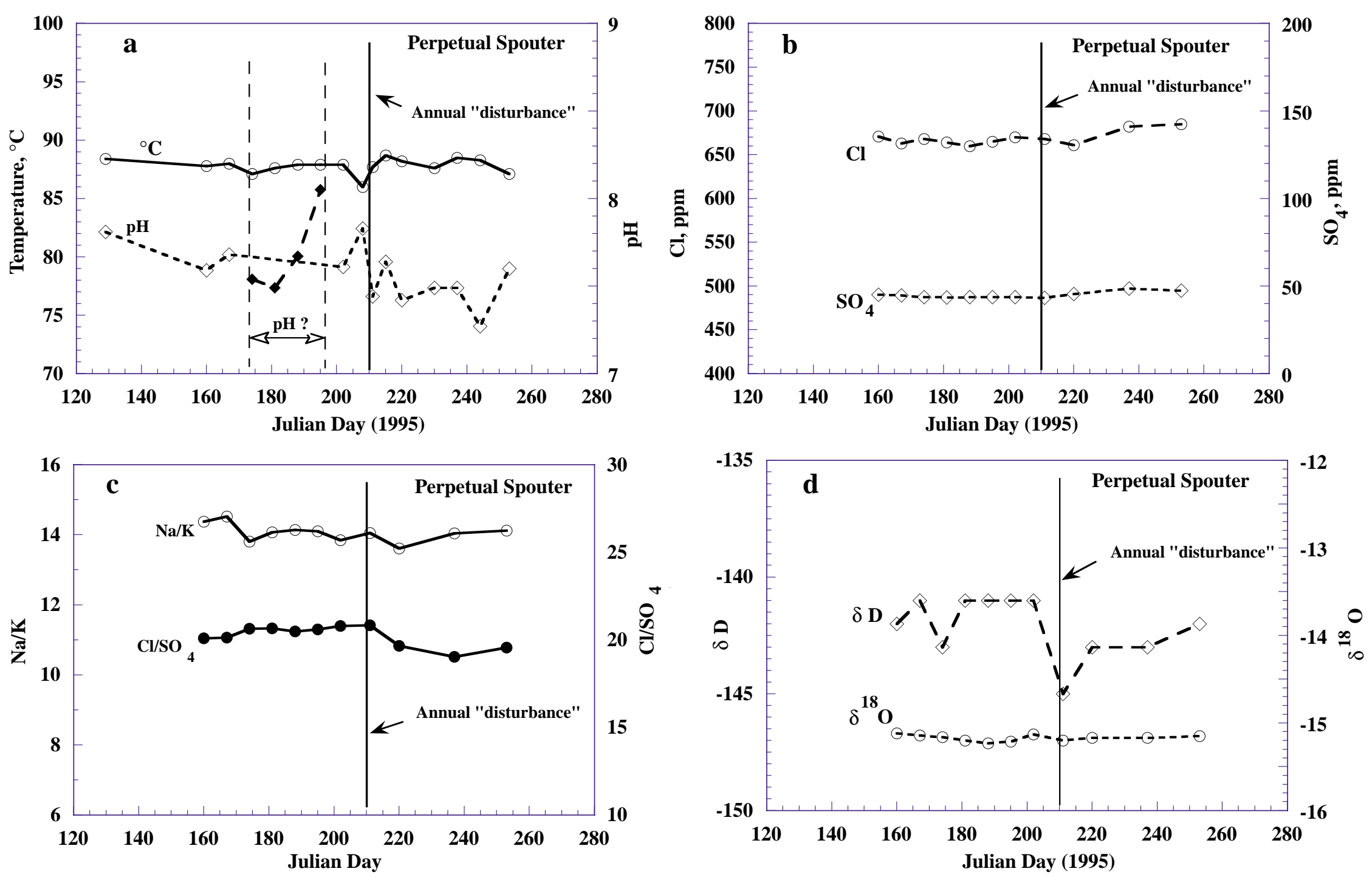

Figure 9 



Figure 10 


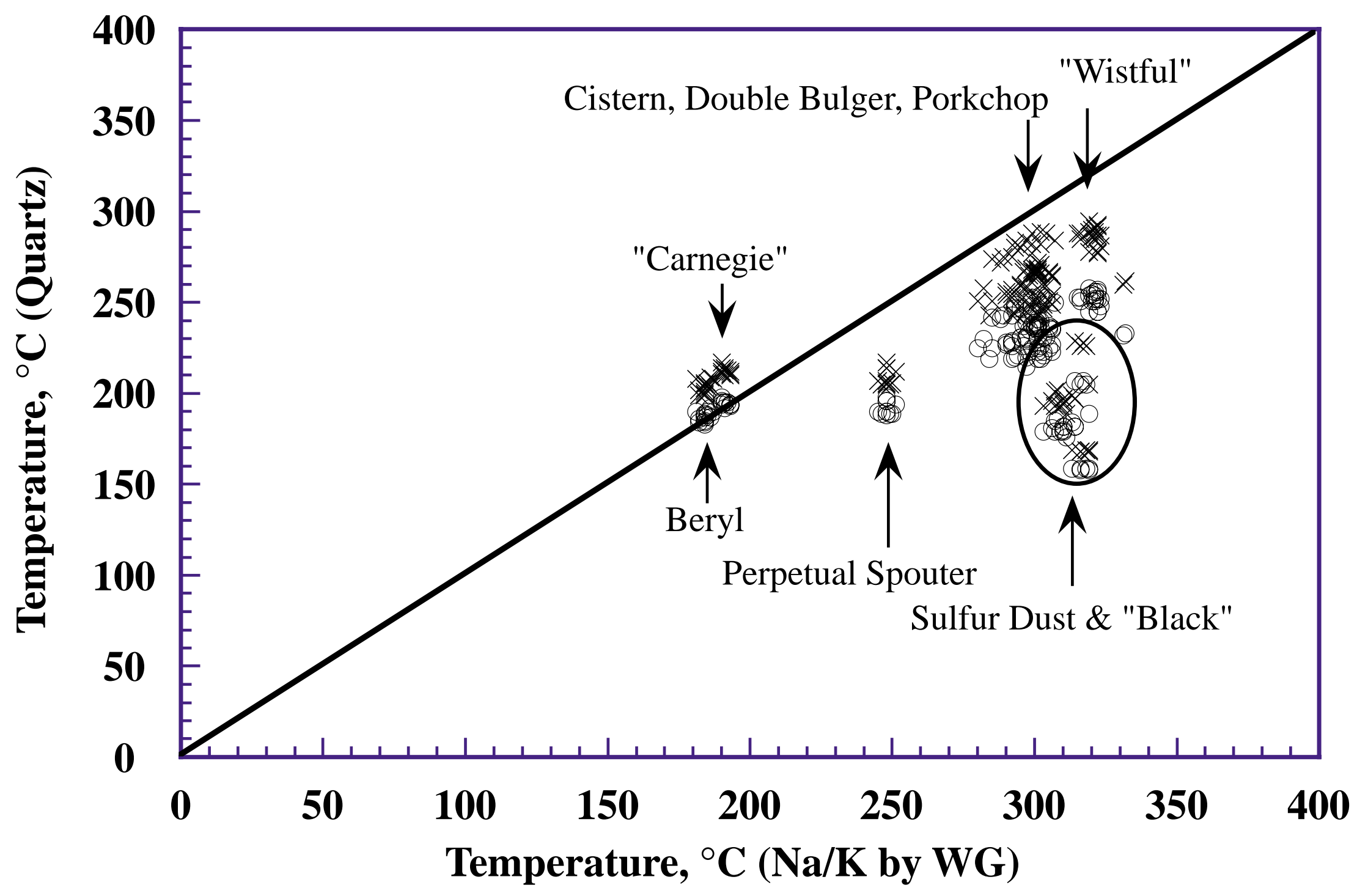

Figure 11 

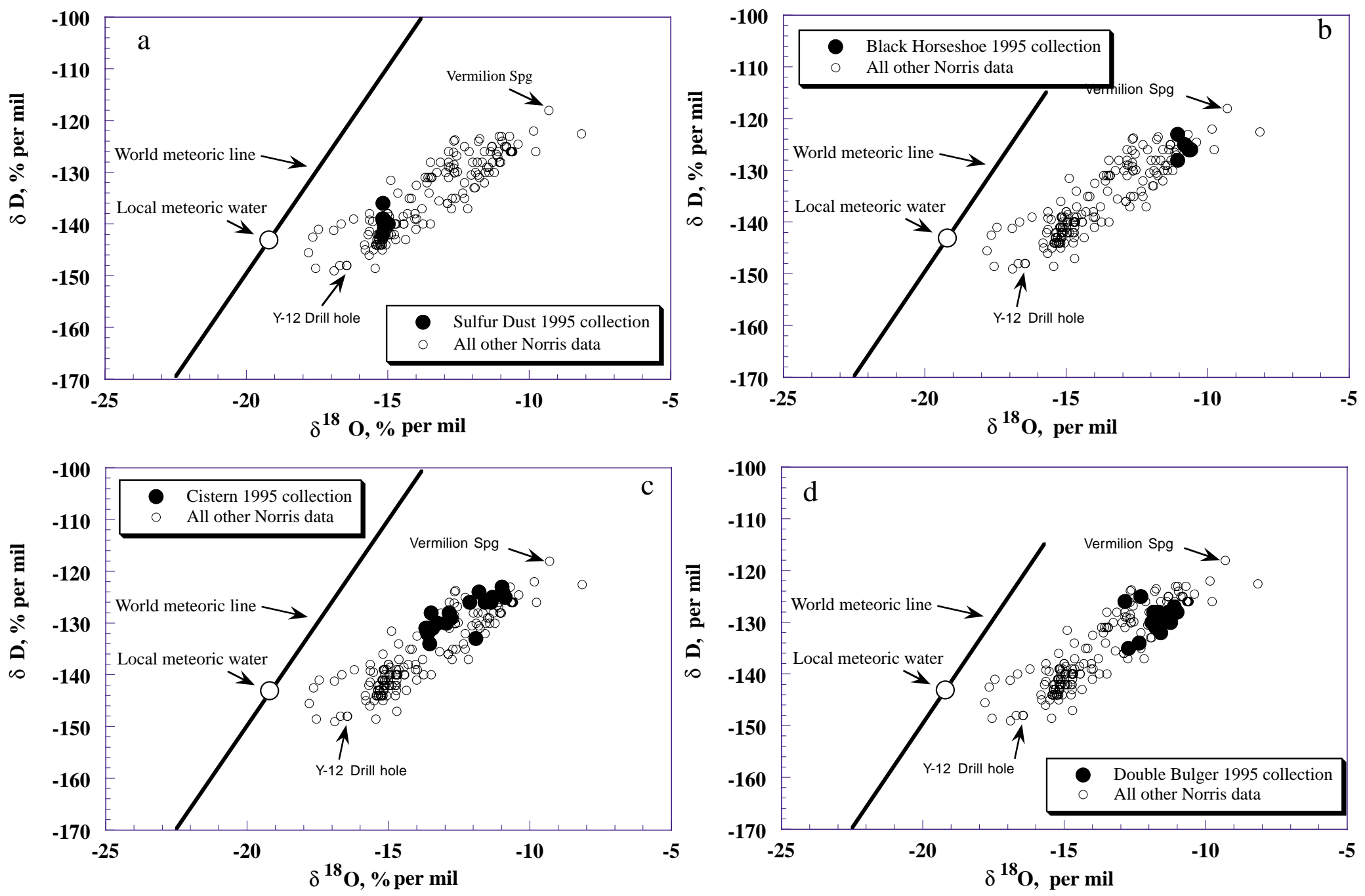

Figure 12 




Figure 13 


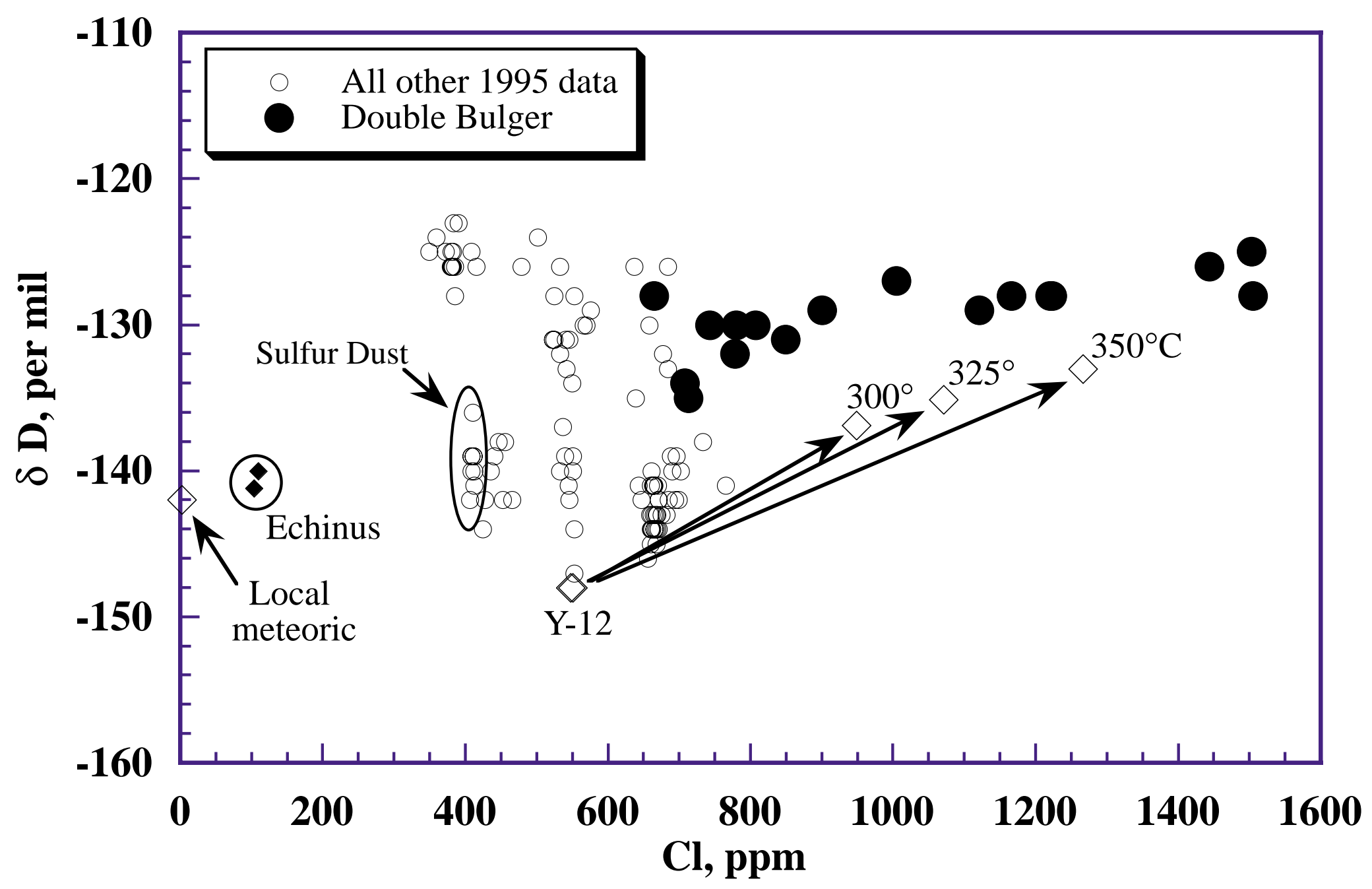

Figure 14 


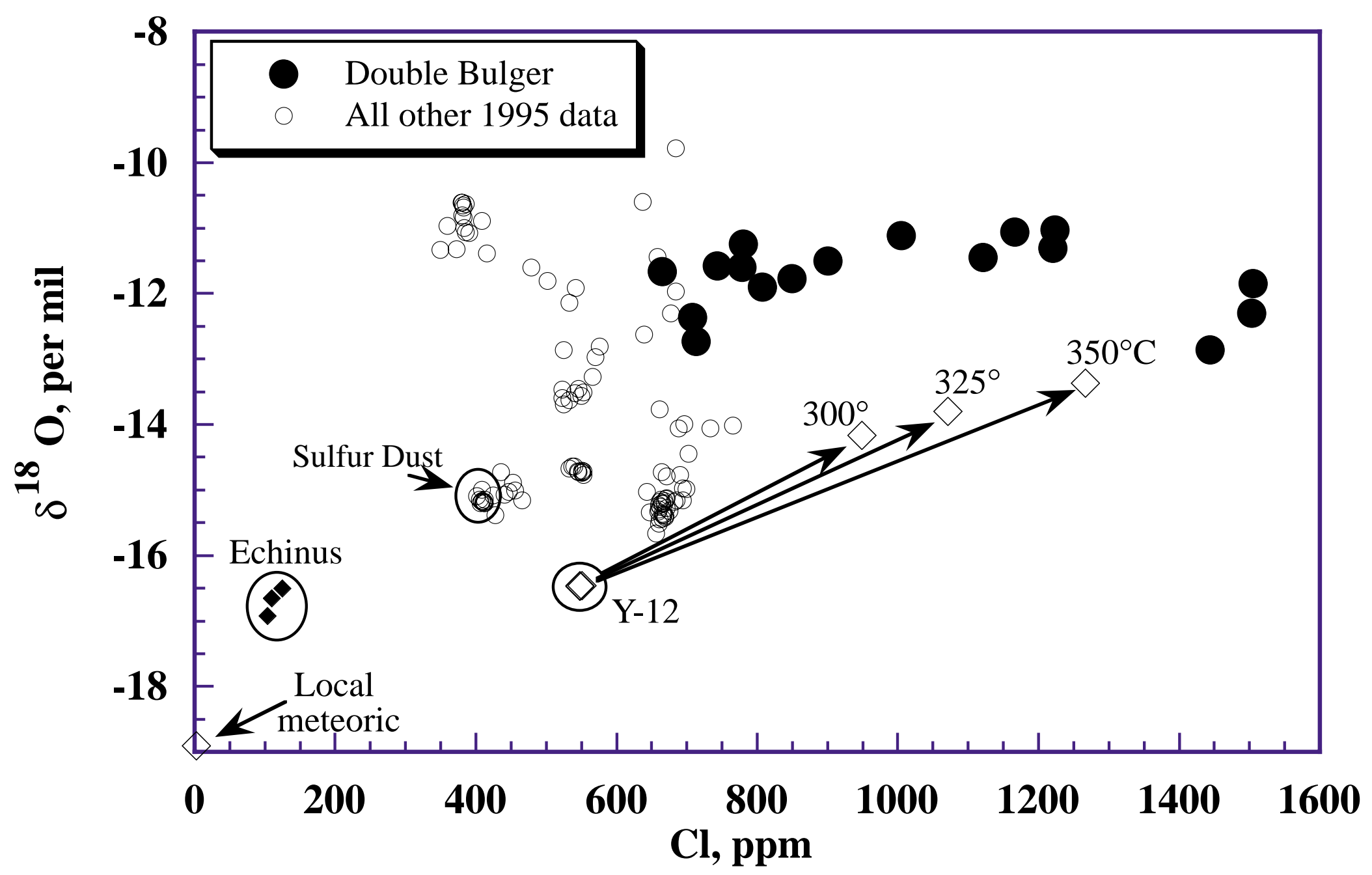

Figure 15 


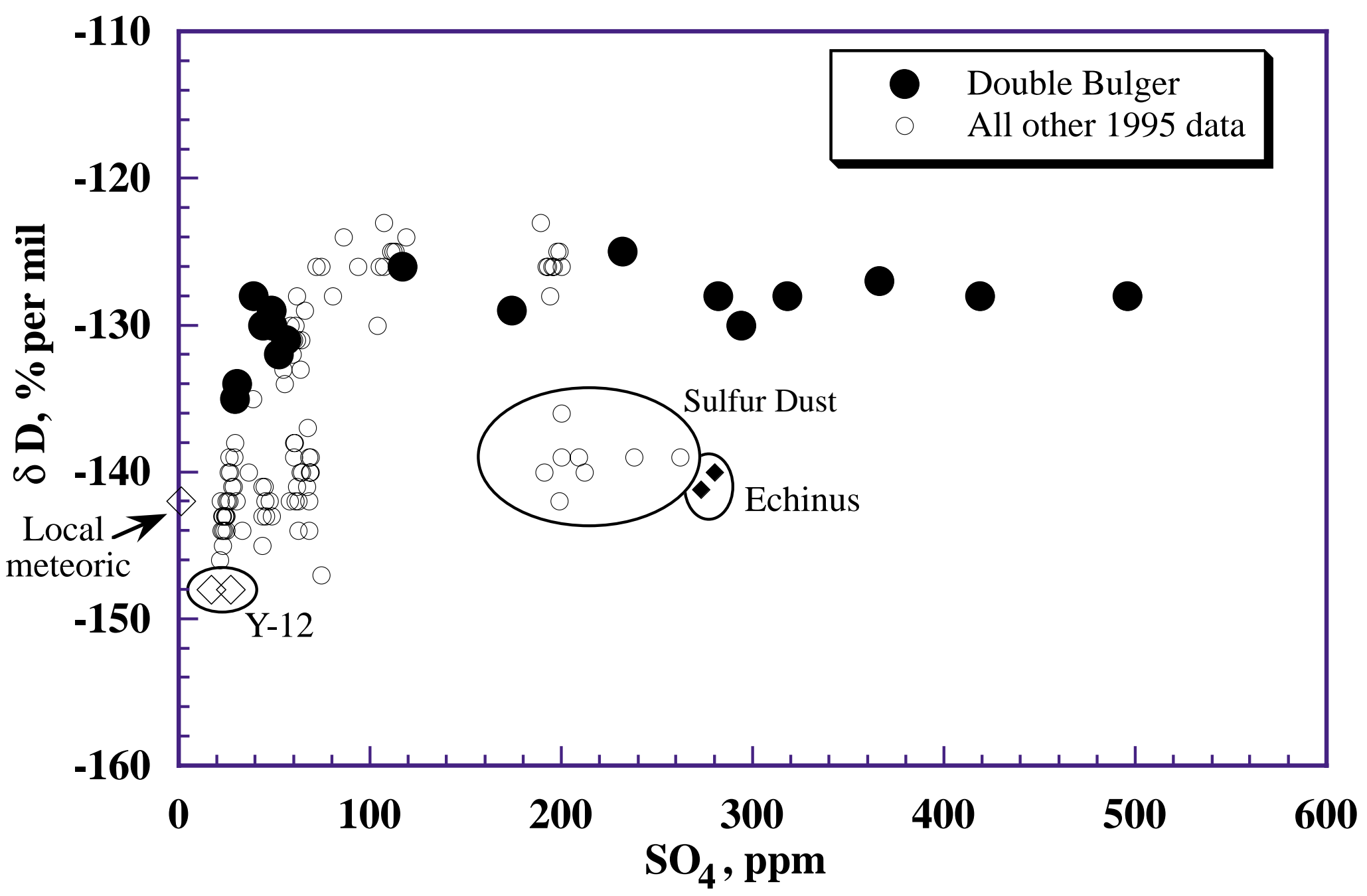

Figure 16 


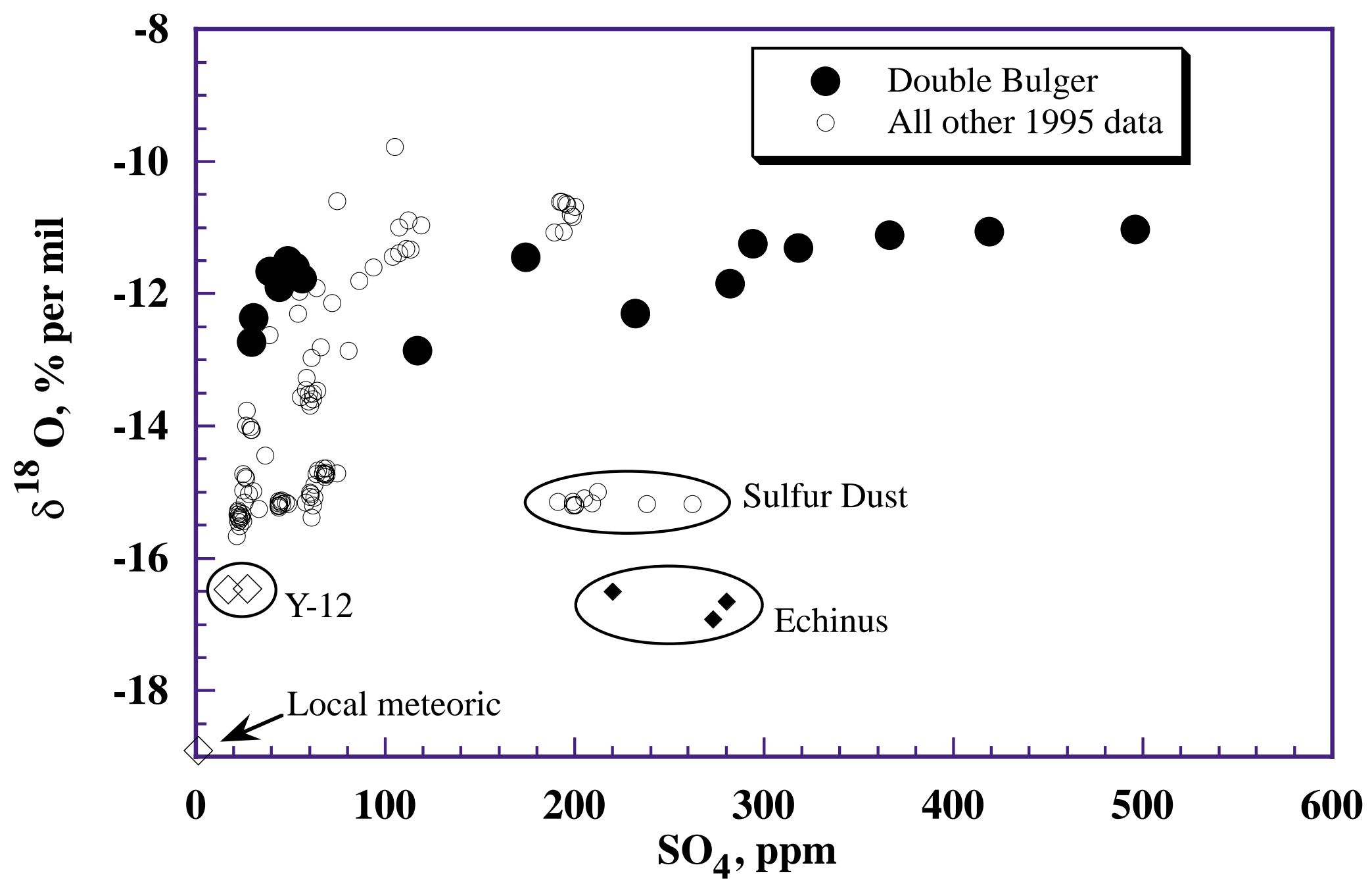

Figure 17 


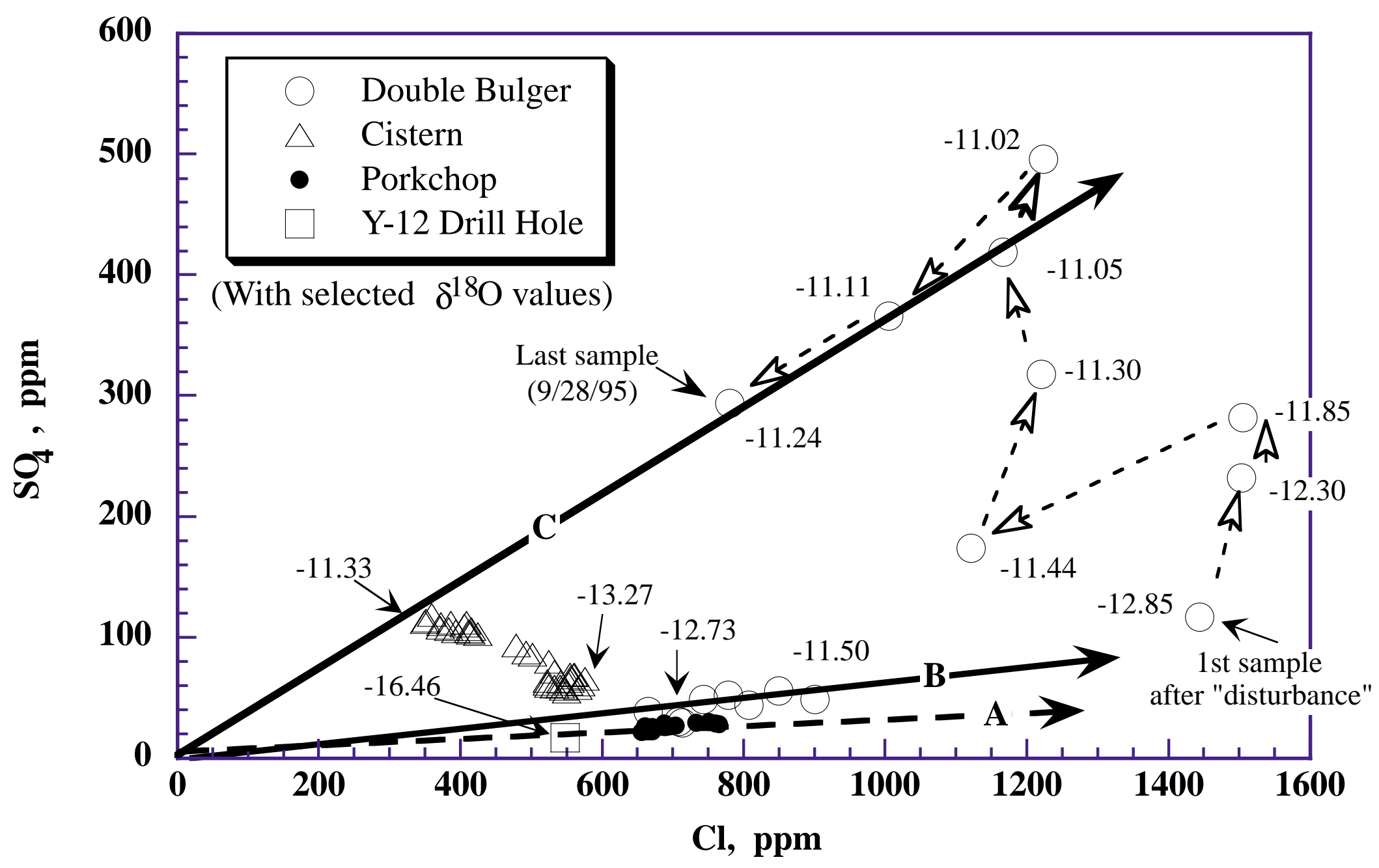

Figure 18 

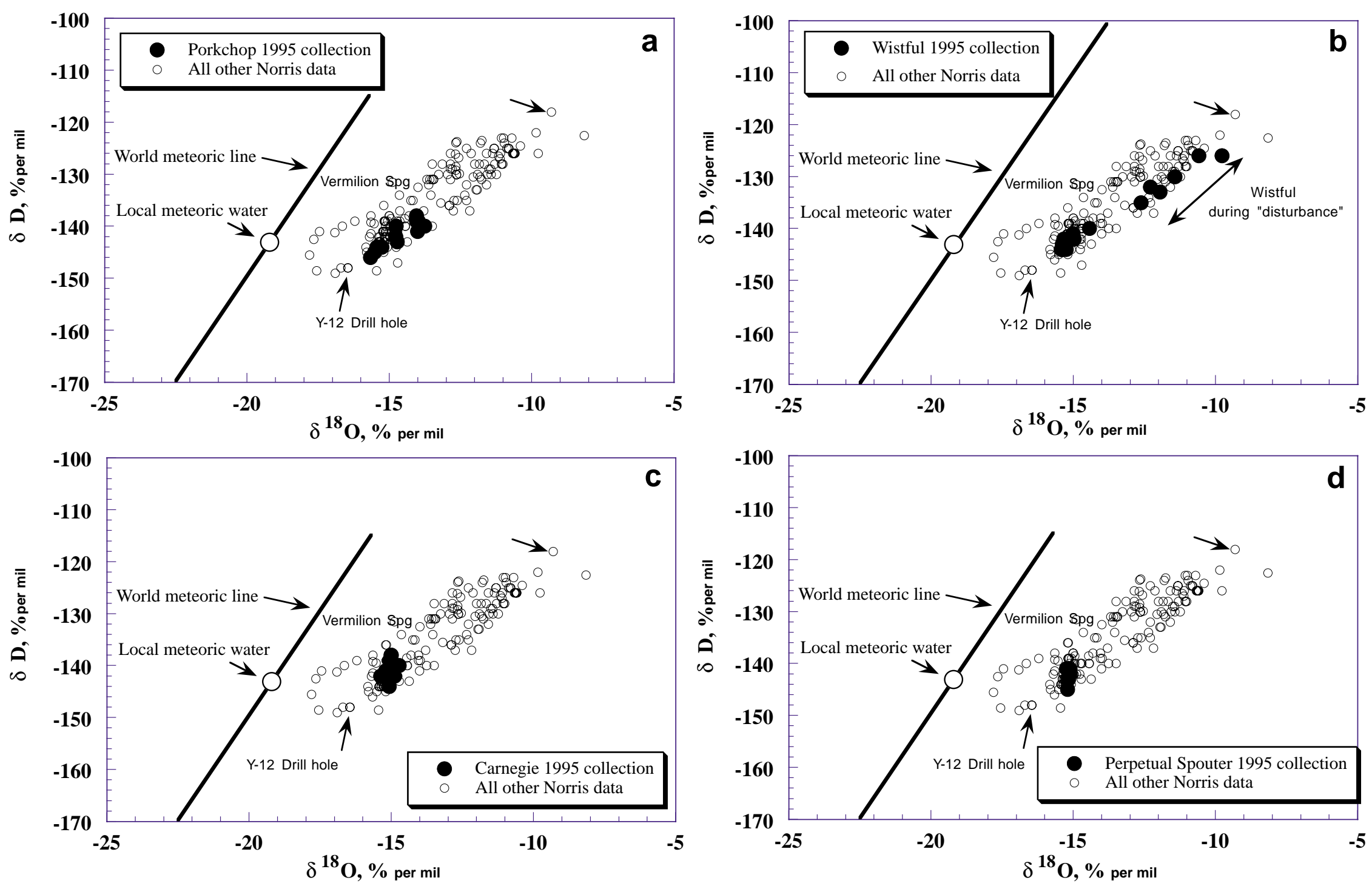

Figure 19 


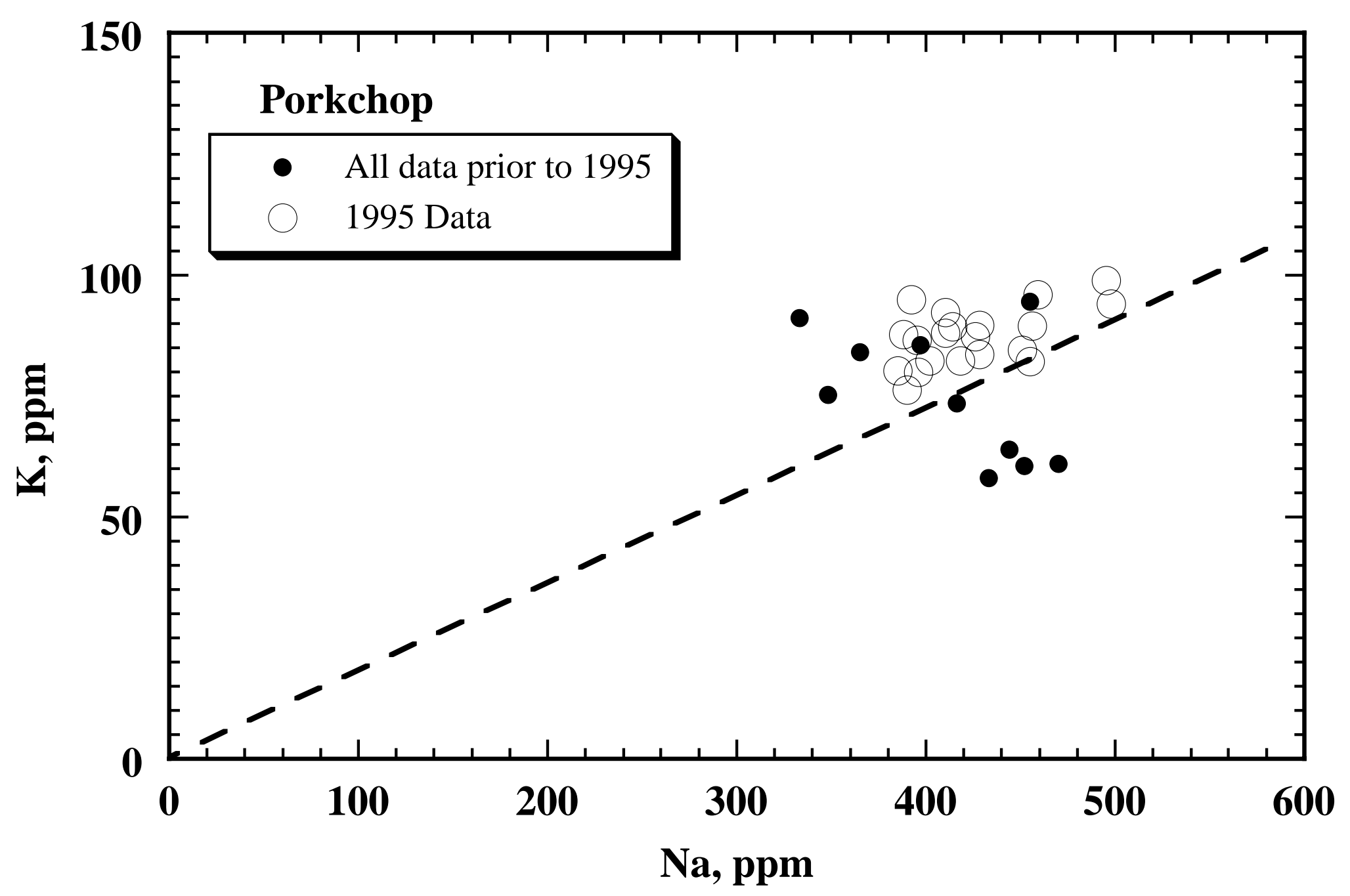

Figure 20 
Table 1. Chemical ${ }^{1}$ and isotopic ${ }^{2}$ analyses of thermal waters collected at Norris Geyser Basin and Gibbon Canyon in 1995

\begin{tabular}{|c|c|c|c|c|c|c|c|c|c|c|c|c|c|c|c|c|}
\hline Name \& Lab Number & Date & Julian Day & $\begin{array}{l}\text { Temp. }{ }^{3} \\
{ }^{\circ} \mathrm{C}\end{array}$ & $\mathrm{H}$ (field) & $\mathrm{pH}$ (lab) & $\begin{array}{c}\mathrm{Na} \\
\mathrm{ppm}\end{array}$ & $\begin{array}{c}\mathrm{K} \\
\mathrm{ppm}\end{array}$ & $\begin{array}{l}\mathrm{Br} \\
\mathrm{ppm}\end{array}$ & $\begin{array}{l}\mathrm{Cl} \\
\mathrm{ppm}\end{array}$ & $\begin{array}{l}\mathrm{SO} 4 \\
\mathrm{ppm}\end{array}$ & $\begin{array}{l}\text { F } \\
\text { ppm }\end{array}$ & $\begin{array}{c}\mathrm{CO} 3 \\
\mathrm{ppm}\end{array}$ & $\begin{array}{c}\mathrm{HCO} 3 \\
\mathrm{ppm}\end{array}$ & $\begin{array}{c}\mathrm{SiO} 2 \\
\mathrm{ppm}\end{array}$ & $\begin{array}{l}\delta \mathrm{D} \\
\% \mathrm{o}\end{array}$ & $\begin{array}{c}\delta^{18} \mathrm{O} \\
\% \mathrm{o}\end{array}$ \\
\hline \multicolumn{17}{|l|}{ Beryl } \\
\hline BS2 & $6 / 8 / 95$ & 159 & 91.1 & 6.75 & 6.75 & 422 & 21.5 & 1.68 & 539 & 68.9 & 17.70 & 12.8 & 99.2 & 282 & -139 & -14.64 \\
\hline BS3 & $6 / 15 / 95$ & 166 & 91.6 & 6.81 & 6.81 & 424 & 22.2 & 1.62 & 536 & 67.5 & 17.70 & 12.1 & 102 & 300 & -137 & -14.63 \\
\hline BS4 & $6 / 22 / 95$ & 173 & 90.4 & 6.64 & 6.64 & 424 & 22.2 & 1.71 & 550 & 68.9 & 17.90 & 11.7 & 102 & 278 & -140 & -14.73 \\
\hline BS5 & $6 / 29 / 95$ & 180 & 90.6 & 6.72 & 6.72 & 412 & 21.3 & 1.68 & 551 & 68.5 & 18.10 & 13.1 & 97.7 & 289 & -140 & -14.70 \\
\hline BS6 & $7 / 6 / 95$ & 187 & 90.5 & 6.45 & 6.45 & 420 & 20.4 & 1.62 & 544 & 66.8 & 17.90 & 11.7 & 102 & 293 & -141 & -14.71 \\
\hline BS7 & $7 / 13 / 95$ & 194 & 90.6 & 7.18 & 7.98 & 417 & 21.2 & 1.69 & 532 & 64.5 & 17.60 & 11.8 & 103 & 287 & -140 & -14.67 \\
\hline BS8 & 7/19/95 & 200 & 90.7 & 6.97 & 6.97 & 427 & 22.7 & 1.79 & 551 & 67.9 & 18.20 & 12.3 & 99.7 & 293 & -139 & -14.72 \\
\hline BS9 & $7 / 27 / 95$ & 208 & 90.7 & 7.05 & & 419 & 21.5 & 1.66 & 552 & 68.2 & 18.20 & & & 276 & -144 & -14.76 \\
\hline BS10 & $8 / 2 / 95$ & 214 & 91.4 & 7.05 & & 412 & 20.9 & 1.55 & 542 & 68.0 & 18.00 & & & 268 & & \\
\hline BS11 & $8 / 9 / 95$ & 221 & 91.3 & 6.73 & & 427 & 21.1 & 1.47 & 546 & 67.8 & 17.80 & & & 263 & & \\
\hline BS12 & $8 / 17 / 95$ & 229 & 91.1 & 6.90 & & 412 & 20.9 & 1.73 & 552 & 74.5 & 18.50 & & & 261 & -147 & -14.71 \\
\hline BS13 & $8 / 24 / 95$ & 236 & 91.5 & 7.00 & & 425 & 21.8 & 1.62 & 551 & 68.7 & 18.10 & & & 265 & & \\
\hline BS14 & $8 / 31 / 95$ & 243 & 90.6 & 6.60 & & 421 & 22.0 & 1.55 & 547 & 68.3 & 18.10 & & & 280 & & \\
\hline BS15 & $9 / 8 / 95$ & 251 & 91.4 & 6.92 & & 421 & 20.9 & 1.75 & 545 & 68.2 & 18.10 & & & 274 & -142 & -14.72 \\
\hline \multicolumn{17}{|l|}{ “Black" } \\
\hline & $5 / 9 / 95$ & 129 & 87.7 & 3.42 & & & & & & & & & & & & \\
\hline BH2 & 6/9/95 & 160 & 87.5 & 3.15 & 2.89 & 252 & 60.3 & 1.25 & 380 & 193 & 3.22 & 0 & 0 & 169 & -126 & -10.62 \\
\hline $\mathrm{BH} 3$ & $6 / 16 / 95$ & 167 & 88.6 & 3.16 & 2.83 & 252 & 63.4 & 1.25 & 385 & 195 & 3.33 & 0 & 0 & 169 & -126 & -10.62 \\
\hline BH4 & $6 / 23 / 95$ & 174 & 87.0 & 3.17 & 2.82 & 244 & 61.6 & 1.23 & 381 & 196 & 3.29 & 0 & 0 & 166 & -126 & -10.65 \\
\hline BH5 & $6 / 30 / 95$ & 181 & 87.7 & 3.26 & 2.84 & 247 & 62.3 & 1.28 & 379 & 192 & 3.27 & 0 & 0 & 166 & -126 & -10.60 \\
\hline BH6 & $7 / 7 / 95$ & 188 & 87.7 & 3.70 & 2.80 & 243 & 59.9 & 1.17 & 382 & 200 & 3.26 & 0 & 0 & 168 & -126 & -10.68 \\
\hline BH7 & 7/14/95 & 195 & 87.5 & 4.66 & 2.82 & 245 & 61.3 & 1.23 & 380 & 198 & 3.24 & 0 & 0 & 169 & -125 & -10.80 \\
\hline BH8 & $7 / 21 / 95$ & 202 & 88.1 & 3.08 & 2.81 & 245 & 60.3 & 1.27 & 382 & 199 & 3.33 & 0 & 0 & 166 & -125 & -10.83 \\
\hline BH9 & $7 / 27 / 95$ & 208 & 87.4 & 3.52 & & 235 & 58.7 & 1.12 & 385 & 195 & 3.31 & & & 370 & & \\
\hline BH10 & 7/30/95 & 211 & 88.2 & 3.18 & & & & & & & & & & & & \\
\hline BH11 & $8 / 3 / 95$ & 215 & 85.8 & 3.18 & & 236 & 57.8 & 1.08 & 385 & 194 & 3.27 & & & 368 & -128 & -11.06 \\
\hline BH12 & $8 / 8 / 95$ & 220 & 87.6 & 3.18 & & & & & & & & & & & & \\
\hline BH13 & $8 / 18 / 95$ & 230 & 88.4 & 2.95 & & 242 & 59.7 & 1.14 & 388 & 190 & 3.20 & & & 379 & & \\
\hline BH14 & $8 / 25 / 95$ & 237 & 88.8 & 2.96 & & & & & & & & & & & & \\
\hline BH15 & $9 / 1 / 95$ & 244 & 90.4 & 2.59 & & 255 & 61.5 & 1.06 & 390 & 189 & 3.22 & & & 381 & -123 & -11.07 \\
\hline BH16 & 9/10/95 & 253 & 89.9 & 2.86 & & & & & & & & & & & & \\
\hline \multicolumn{17}{|l|}{ "Carnegie" } \\
\hline & $5 / 9 / 95$ & 129 & 87.8 & 5.72 & & & & & & & & & & & & \\
\hline CD2 & $6 / 10 / 95$ & 161 & 87.4 & 5.94 & 6.79 & 301 & 17.1 & 1.34 & 412 & 61.7 & 6.59 & 0 & 5.8 & 302 & -141 & -15.20 \\
\hline CD3 & $6 / 17 / 95$ & 168 & 86.7 & 6.06 & 6.87 & 307 & 17.8 & 1.48 & 424 & 62.2 & 6.80 & 0 & 7.1 & 315 & -144 & -15.08 \\
\hline CD4 & $6 / 24 / 95$ & 175 & 86.3 & 6.32 & 6.88 & 302 & 17.7 & 1.44 & 427 & 61.0 & 6.80 & 0 & 8.3 & 312 & -142 & -15.38 \\
\hline CD5 & $7 / 1 / 95$ & 182 & 86.6 & 6.52 & 6.90 & 306 & 17.3 & 1.50 & 446 & 60.4 & 6.85 & 0 & 8.3 & 315 & -138 & -15.02 \\
\hline CD6 & 7/8/95 & 189 & 87.8 & 6.34 & 6.89 & 311 & 17.5 & 1.35 & 455 & 60.2 & 6.82 & 0 & 8.4 & 312 & -138 & -15.00 \\
\hline CD7 & $7 / 15 / 95$ & 196 & 87.5 & & 6.98 & 297 & 16.7 & 1.47 & 440 & 60.0 & 6.72 & 0 & 9.1 & 308 & -139 & -15.06 \\
\hline CD8 & $7 / 22 / 95$ & 203 & 88.4 & 6.42 & & 300 & 17.5 & 1.50 & 461 & 58.9 & 6.85 & & & 308 & & \\
\hline CD9 & $7 / 28 / 95$ & 209 & 89.3 & 6.34 & & 311 & 18.3 & 1.62 & 465 & 58 & 6.64 & & & 304 & -142 & -15.15 \\
\hline CD10 & $7 / 29 / 95$ & 210 & 86.1 & 6.76 & & 310 & 17.4 & 1.48 & 464 & 60.6 & 6.50 & & & 317 & & \\
\hline CD11 & $8 / 1 / 95$ & 213 & 88.7 & 6.37 & & 300 & 16.7 & 1.38 & 455 & 61 & 6.50 & & & 319 & & \\
\hline CD12 & $8 / 4 / 95$ & 216 & 88.2 & 6.28 & & & & & & & & & & & & \\
\hline CD13 & $8 / 8 / 95$ & 220 & 87.7 & 6.32 & & & & & & & & & & & & \\
\hline CD14 & $8 / 21 / 95$ & 233 & 87.7 & 5.89 & & 287 & 16.2 & 1.27 & 452 & 62.3 & 6.43 & & & 317 & -142 & -14.88 \\
\hline
\end{tabular}




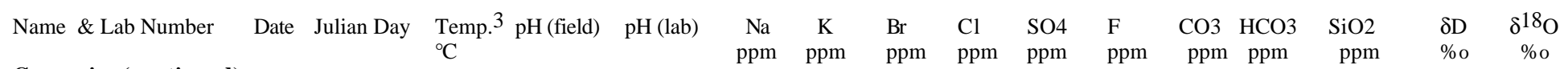
Carnegie (continued)

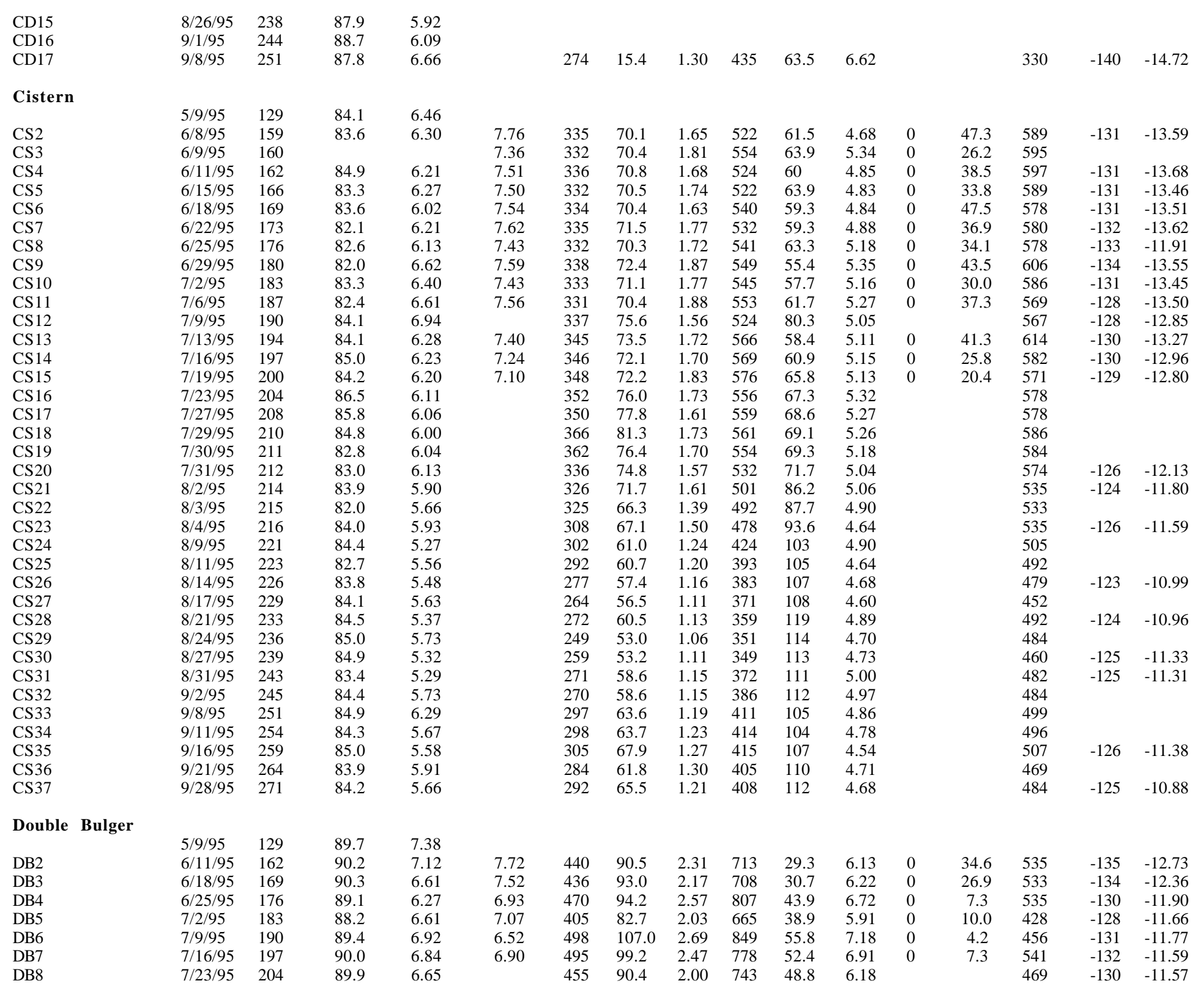




\begin{tabular}{|c|c|c|c|c|c|c|c|c|c|c|c|c|c|c|c|c|}
\hline Name \& Lab Number & Date & Julian Day & $\begin{array}{l}\text { Temp. }{ }^{3} \\
{ }^{\circ} \mathrm{C}\end{array}$ & pH (field) & $\mathrm{pH}$ (lab) & $\begin{array}{c}\mathrm{Na} \\
\mathrm{ppm}\end{array}$ & $\begin{array}{c}\mathrm{K} \\
\mathrm{ppm}\end{array}$ & $\begin{array}{l}\mathrm{Br} \\
\mathrm{ppm}\end{array}$ & $\begin{array}{l}\mathrm{Cl} \\
\mathrm{ppm}\end{array}$ & $\begin{array}{l}\mathrm{SO} 4 \\
\mathrm{ppm}\end{array}$ & $\begin{array}{l}\text { F } \\
\text { ppm }\end{array}$ & $\begin{array}{c}\mathrm{CO} 3 \\
\mathrm{ppm}\end{array}$ & $\begin{array}{l}\mathrm{HCO} 3 \\
\mathrm{ppm}\end{array}$ & $\begin{array}{r}\mathrm{SiO} 2 \\
\text { ppm }\end{array}$ & $\begin{array}{l}\delta \mathrm{D} \\
\% \mathrm{o}\end{array}$ & $\begin{array}{c}\delta^{18} \mathrm{O} \\
\% \mathrm{o}\end{array}$ \\
\hline \multicolumn{17}{|c|}{ Double Bulger (continued) } \\
\hline DB9 & $7 / 29 / 95$ & 210 & 89.9 & 6.66 & & 551 & 107.0 & 2.61 & 900 & 48.5 & 7.20 & & & 524 & -129 & -11.50 \\
\hline DB10 & $8 / 9 / 95$ & 221 & 92.1 & 5.95 & & 833 & 144.0 & 4.16 & 1444 & 117 & 6.90 & & & 492 & -126 & -12.85 \\
\hline DB11 & $8 / 14 / 95$ & 226 & 90.8 & 4.85 & & 771 & 151.0 & 4.26 & 1503 & 232 & 6.53 & & & 501 & -125 & -12.30 \\
\hline DB12 & $8 / 21 / 95$ & 233 & 90.8 & 4.28 & & 877 & 167.0 & 4.38 & 1505 & 282 & 4.91 & & & 511 & -128 & -11.84 \\
\hline DB13 & $8 / 27 / 95$ & 239 & 90.0 & 4.02 & & 671 & 121.0 & 3.24 & 1121 & 174 & 5.11 & & & 452 & -129 & -11.44 \\
\hline DB14 & 9/2/95 & 245 & 90.0 & 2.88 & & 721 & 138.0 & 3.77 & 1220 & 318 & 3.73 & & & 518 & -128 & -11.30 \\
\hline DB15 & 9/9/95 & 252 & 89.7 & 2.83 & & 687 & 125.0 & 3.74 & 1166 & 419 & 3.16 & & & 492 & -128 & -11.05 \\
\hline DB16 & 9/16/95 & 259 & 89.5 & 2.35 & & 762 & 134.0 & 3.91 & 1223 & 496 & 3.61 & & & 531 & -128 & -11.02 \\
\hline DB17 & 9/21/95 & 264 & 90.0 & 2.83 & & 596 & 117.0 & 3.24 & 1005 & 366 & 4.30 & & & 458 & -127 & -11.11 \\
\hline DB18 & $9 / 28 / 95$ & 271 & 89.3 & 3.16 & & 491 & 96.0 & 2.20 & 780 & 294 & 3.78 & & & 452 & -130 & -11.24 \\
\hline Perpetual Spouter & & & & & & & & & & & & & & & & \\
\hline & $5 / 9 / 95$ & 129 & 88.4 & 7.81 & & & & & & & & & & & & \\
\hline PS2 & $6 / 9 / 95$ & 160 & 87.8 & 7.59 & 7.97 & 405 & 47.9 & 2.61 & 671 & 45.2 & 6.19 & 8.6 & 3.5 & 285 & -142 & -15.12 \\
\hline PS3 & 6/16/95 & 167 & 88.0 & 7.68 & 8.02 & 428 & 50.1 & 2.21 & 663 & 44.6 & 6.14 & 9.3 & 2.1 & 291 & -141 & -15.14 \\
\hline PS4 & $6 / 23 / 95$ & 174 & 87.1 & 7.54 & 8.00 & 428 & 52.7 & 2.05 & 668 & 43.8 & 6.34 & 9.3 & 1.9 & 287 & -143 & -15.16 \\
\hline PS5 & $6 / 30 / 95$ & 181 & 87.6 & 7.49 & 7.81 & 419 & 50.6 & 2.24 & 664 & 43.5 & 6.38 & 6.9 & 6.5 & 291 & -141 & -15.20 \\
\hline PS6 & 7/7/95 & 188 & 87.9 & 7.67 & 7.99 & 406 & 48.8 & 2.36 & 660 & 43.6 & 6.19 & 8.8 & 2.5 & 282 & -141 & -15.23 \\
\hline PS7 & $7 / 14 / 95$ & 195 & 87.9 & 8.05 & 8.00 & 394 & 47.5 & 2.47 & 665 & 43.7 & 5.98 & 9.2 & 1 & 289 & -141 & -15.21 \\
\hline PS8 & $7 / 21 / 95$ & 202 & 87.9 & 7.61 & 7.98 & 413 & 50.7 & 2.19 & 670 & 43.6 & 6.25 & 9.1 & 1.2 & 285 & -141 & -15.13 \\
\hline PS9 & $7 / 27 / 95$ & 208 & 86.0 & 7.83 & & & & & & & & & & & & \\
\hline PS10 & $7 / 30 / 95$ & 211 & 87.7 & 7.44 & & 406 & 49.1 & 2.01 & 668 & 43.4 & 5.76 & & & 319 & -145 & -15.20 \\
\hline PS11 & $8 / 3 / 95$ & 215 & 88.7 & 7.64 & & & & & & & & & & & & \\
\hline PS12 & 8/8/95 & 220 & 88.2 & 7.42 & & 410 & 51.2 & 2.04 & 661 & 45.5 & 5.45 & & & 312 & -143 & -15.17 \\
\hline PS13 & $8 / 18 / 95$ & 230 & 87.6 & 7.49 & & & & & & & & & & & & \\
\hline PS14 & $8 / 25 / 95$ & 237 & 88.5 & 7.49 & & 432 & 52.3 & 2.11 & 682 & 48.5 & 5.79 & & & 330 & -143 & -15.17 \\
\hline PS15 & $9 / 1 / 95$ & 244 & 88.3 & 7.27 & & & & & & & & & & & & \\
\hline PS 16 & 9/10/95 & 253 & 87.1 & 7.60 & & 417 & 50.2 & 1.95 & 685 & 47.4 & 6.06 & & & 319 & -142 & -15.15 \\
\hline \multicolumn{17}{|l|}{ Porkchop } \\
\hline & $5 / 9 / 95$ & 129 & 59.6 & 7.88 & & & & & & & & & & & & \\
\hline $\mathrm{PC} 2$ & $6 / 11 / 95$ & 162 & 54.6 & 7.42 & 7.94 & 390 & 76.3 & 2.27 & 661 & 26.6 & 6.59 & 9 & 48 & 516 & -140 & -13.76 \\
\hline $\mathrm{PC} 3$ & $6 / 18 / 95$ & 169 & 71.3 & 7.50 & 8.18 & 396 & 80.0 & 2.09 & 664 & 24.7 & 6.36 & 13.8 & 19.6 & 582 & -143 & -14.72 \\
\hline PC4 & $6 / 25 / 95$ & 176 & 74.4 & 7.50 & 8.27 & 402 & 82.3 & 2.31 & 671 & 26.2 & 6.76 & 15.4 & 12 & 597 & -142 & -14.78 \\
\hline PC5 & $7 / 2 / 95$ & 183 & 83.5 & 8.10 & 8.81 & 385 & 80.3 & 2.14 & 660 & 22.2 & 6.37 & 14.5 & 0 & 721 & -144 & -15.29 \\
\hline PC6 & $7 / 9 / 95$ & 190 & 85.8 & 8.26 & 8.83 & 395 & 86.6 & 2.45 & 667 & 22.4 & 6.32 & 15.1 & 0 & 721 & -144 & -15.37 \\
\hline PC7 & $7 / 16 / 95$ & 197 & 86.5 & 8.00 & 8.88 & 388 & 87.7 & 2.33 & 661 & 22.1 & 6.14 & 13.1 & 0 & 719 & -144 & -15.44 \\
\hline PC8 & $7 / 23 / 95$ & 204 & 86.0 & 7.93 & & 414 & 89.4 & 2.07 & 671 & 22.3 & 5.76 & & & 725 & -144 & -15.27 \\
\hline PC9 & $7 / 29 / 95$ & 210 & 91.0 & 7.99 & & 392 & 95.0 & 1.66 & 656 & 21.4 & 5.69 & & & 717 & -146 & -15.66 \\
\hline $\mathrm{PC} 10$ & $7 / 30 / 95$ & 211 & 92.2 & 7.87 & & 410 & 92.3 & 2.18 & 660 & 22.8 & 5.74 & & & 693 & -145 & -15.51 \\
\hline PC11 & $7 / 31 / 95$ & 212 & 91.7 & 8.28 & & 410 & 88.1 & 1.75 & 667 & 23.1 & 5.91 & & & 681 & & \\
\hline PC12 & $8 / 2 / 95$ & 214 & 82.3 & 7.23 & & 426 & 87.3 & 1.86 & 687 & 26 & 5.73 & & & 693 & & \\
\hline PC13 & $8 / 3 / 95$ & 215 & 88.4 & 6.93 & & & & & & & & & & & & \\
\hline PC14 & $8 / 4 / 95$ & 216 & 86.9 & 7.06 & & 418 & 82.3 & 2.04 & 691 & 27 & 6.12 & & & 685 & & \\
\hline PC15 & $8 / 6 / 95$ & 218 & 86.5 & 6.62 & & 428 & 89.6 & 2.20 & 690 & 25.7 & 5.92 & & & 646 & -140 & -14.77 \\
\hline PC16 & $8 / 8 / 95$ & 220 & 83.1 & 6.36 & & 428 & 83.6 & 2.17 & 688 & 29.1 & 5.92 & & & 631 & -139 & -14.05 \\
\hline PC17 & $8 / 9 / 95$ & 221 & 82.4 & 6.24 & & & & & & & & & & & & \\
\hline PC18 & $8 / 11 / 95$ & 223 & 83.3 & 6.45 & & 455 & 82.2 & 2.06 & 696 & 26.4 & 6.47 & & & 627 & -139 & -13.99 \\
\hline PC19 & $8 / 14 / 95$ & 226 & 82.8 & 6.33 & & 451 & 84.6 & 2.11 & 704 & 27 & 7.07 & & & 616 & & \\
\hline
\end{tabular}




\begin{tabular}{|c|c|c|c|c|c|c|c|c|c|c|c|c|c|c|c|c|}
\hline Name \& Lab Number & Date & Julian Day & $\begin{array}{l}\text { Temp. }{ }^{3} \\
{ }^{\circ} \mathrm{C}\end{array}$ & pH (field) & $\mathrm{pH}(\mathrm{lab})$ & $\begin{array}{c}\mathrm{Na} \\
\mathrm{ppm}\end{array}$ & $\begin{array}{c}\mathrm{K} \\
\mathrm{ppm}\end{array}$ & $\begin{array}{l}\mathrm{Br} \\
\mathrm{ppm}\end{array}$ & $\begin{array}{l}\mathrm{Cl} \\
\mathrm{ppm}\end{array}$ & $\begin{array}{l}\text { SO4 } \\
\text { ppm }\end{array}$ & $\begin{array}{l}\mathrm{F} \\
\mathrm{ppm}\end{array}$ & $\begin{array}{c}\mathrm{CO} 3 \\
\mathrm{ppm}\end{array}$ & $\begin{array}{c}\mathrm{HCO} 3 \\
\mathrm{ppm}\end{array}$ & $\begin{array}{c}\mathrm{SiO} 2 \\
\text { ppm }\end{array}$ & $\begin{array}{l}\delta \mathrm{D} \\
\% \mathrm{o}\end{array}$ & $\begin{array}{c}\delta^{18} \mathrm{O} \\
\% \mathrm{o}\end{array}$ \\
\hline \multicolumn{17}{|c|}{ Porkchop (continued) } \\
\hline $\mathrm{PC} 20$ & $8 / 21 / 95$ & 233 & 79.9 & 7.26 & & 456 & 89.5 & 2.32 & 733 & 29.2 & 7.79 & & & 666 & -138 & -14.05 \\
\hline PC21 & $8 / 27 / 95$ & 239 & 80.2 & 7.20 & & 459 & 96.0 & 2.14 & 751 & 30.1 & 7.63 & & & 678 & & \\
\hline PC22 & 9/2/95 & 245 & 78.6 & 7.42 & & 495 & 99.0 & 2.52 & 760 & 28.8 & 7.57 & & & 666 & & \\
\hline $\mathrm{PC} 23$ & 9/9/95 & 252 & 73.2 & 7.86 & & 498 & 94.0 & 2.42 & 765 & 28.4 & 7.01 & & & 633 & -141 & -14.01 \\
\hline \multicolumn{17}{|l|}{ Sulphur Dust } \\
\hline & $5 / 9 / 95$ & 129 & 47.4 & 2.88 & & & & & & & & & & & & \\
\hline SD2 & $6 / 9 / 95$ & 160 & 45.3 & 2.88 & 2.52 & 252 & 54.9 & 1.25 & 411 & 262 & 3.55 & & & 240 & -139 & -15.17 \\
\hline SD3 & $6 / 16 / 95$ & 167 & 46.3 & 2.95 & 2.58 & 252 & 58.4 & 1.22 & 408 & 238 & 3.53 & & & 244 & -139 & -15.17 \\
\hline SD4 & $6 / 23 / 95$ & 174 & 46.5 & 5.23 & 2.73 & 267 & 61.2 & 1.28 & 411 & 200 & 3.44 & & & 242 & -139 & -15.19 \\
\hline SD5 & $6 / 30 / 95$ & 181 & 45.7 & 7.42 & 2.69 & 260 & 60.4 & 1.26 & 408 & 209 & 3.46 & & & 246 & -139 & -15.16 \\
\hline SD6 & $7 / 7 / 95$ & 188 & 45.9 & 8.50 & 2.74 & 261 & 58.9 & 1.21 & 406 & 199 & 3.48 & & & 242 & -142 & -15.19 \\
\hline SD7 & $7 / 14 / 95$ & 195 & 45.6 & 7.86 & 2.68 & 263 & 59.0 & 1.32 & 408 & 212 & 3.56 & & & 250 & -140 & -14.99 \\
\hline SD8 & $7 / 21 / 95$ & 202 & 46.0 & 2.98 & 2.74 & 261 & 61.0 & 1.38 & 410 & 200 & 3.51 & & & 229 & -139 & -15.18 \\
\hline SD9 & $7 / 27 / 95$ & 208 & 45.3 & 3.13 & & 273 & 63.5 & 1.21 & 412 & 191 & 3.30 & & & 253 & -140 & -15.14 \\
\hline SD10 & $7 / 30 / 95$ & 211 & 46.4 & 2.69 & & 249 & 59.9 & 1.17 & 409 & 195 & 3.23 & & & 255 & & \\
\hline SD11 & $8 / 3 / 95$ & 215 & 47.2 & 2.97 & & 274 & 61.6 & 1.15 & 410 & 201 & 3.24 & & & 270 & & \\
\hline SD12 & $8 / 8 / 95$ & 220 & 44.3 & 2.76 & & 253 & 60.5 & 1.15 & 405 & 199 & 3.25 & & & 263 & -139 & -15.14 \\
\hline SD13 & $8 / 18 / 95$ & 230 & 45.9 & 2.75 & & 259 & 60.4 & 1.22 & 404 & 191 & 3.26 & & & 255 & & \\
\hline SD14 & $8 / 24 / 95$ & 236 & 47.3 & 2.76 & & 254 & 61.2 & 1.29 & 404 & 200 & 3.12 & & & 253 & & \\
\hline SD15 & 9/1/95 & 244 & 46.6 & 2.47 & & 257 & 64.6 & 1.31 & 406 & 196 & 3.21 & & & 285 & & \\
\hline SD16 & 9/10/95 & 253 & 44.0 & 2.78 & & 269 & 61.5 & 1.30 & 401 & 205 & 3.10 & & & 274 & -139 & -15.09 \\
\hline \multicolumn{17}{|l|}{ "Wistful" } \\
\hline & $5 / 9 / 95$ & 129 & 88.4 & 8.09 & & & & & & & & & & & & \\
\hline WF2 & $6 / 10 / 95$ & 161 & 86.9 & 7.80 & 8.66 & 407 & 105.0 & 2.25 & 665 & 25 & 6.11 & 0 & 0 & 702 & -144 & -15.43 \\
\hline WF3 & $6 / 17 / 95$ & 168 & 89.6 & 7.80 & 8.66 & 402 & 103.0 & 2.23 & 659 & 24.4 & 6.23 & 0 & 0 & 743 & -143 & -15.32 \\
\hline WF4 & $6 / 24 / 95$ & 175 & 83.7 & 7.88 & 8.65 & 405 & 103.0 & 2.22 & 666 & 24.1 & 6.37 & 0 & 0 & 736 & -143 & -15.38 \\
\hline WF5 & 7/1/95 & 182 & 82.9 & 8.18 & 8.62 & 410 & 107.0 & 2.27 & 669 & 22.9 & 6.33 & 0 & 1.4 & 715 & -144 & -15.41 \\
\hline WF6 & $7 / 8 / 95$ & 189 & 86.0 & 8.02 & 8.66 & 406 & 104.0 & 2.05 & 669 & 22.7 & 6.35 & 0 & 0 & 713 & -143 & -15.39 \\
\hline WF7 & $7 / 15 / 95$ & 196 & 85.2 & & 8.57 & 422 & 109.0 & 1.98 & 665 & 23.5 & 6.27 & 0 & 6.1 & 753 & -144 & -15.35 \\
\hline WF8 & $7 / 22 / 95$ & 203 & 84.9 & 7.94 & 8.63 & 413 & 107.0 & 2.07 & 675 & 23 & 6.17 & 0 & 0 & 751 & -143 & -15.31 \\
\hline WF9 & $7 / 28 / 95$ & 209 & 86.0 & 7.90 & & 393 & 99.0 & 1.93 & 647 & 21.7 & 5.59 & & & 770 & -142 & -15.34 \\
\hline WF10 & $7 / 29 / 95$ & 210 & 80.2 & 8.12 & & 391 & 101.0 & 2.09 & 662 & 33.2 & 5.70 & & & 713 & -144 & -15.25 \\
\hline WF11 & $8 / 1 / 95$ & 213 & 82.9 & 7.28 & & 402 & 101.0 & 1.90 & 643 & 27.6 & 5.50 & & & 730 & -141 & -15.02 \\
\hline WF12 & $8 / 3 / 95$ & 215 & 77.2 & 5.99 & & 390 & 101.0 & 2.18 & 639 & 38.7 & 5.63 & & & 646 & -135 & -12.62 \\
\hline WF13 & $8 / 4 / 95$ & 216 & 85.6 & 4.72 & & 374 & 105.0 & 2.00 & 637 & 74.4 & 4.86 & & & 544 & -126 & -10.59 \\
\hline WF14 & $8 / 6 / 95$ & 218 & 81.3 & 4.39 & & 392 & 111.0 & 1.98 & 684 & 105 & 4.98 & & & 554 & -126 & -9.77 \\
\hline WF15 & $8 / 8 / 95$ & 220 & 71.0 & 5.54 & & 434 & 113.0 & 2.15 & 658 & 104 & 5.64 & & & 651 & -130 & -11.43 \\
\hline WF16 & $8 / 9 / 95$ & 221 & 73.1 & 5.67 & & 415 & 105.0 & 2.16 & 684 & 54.5 & 6.21 & & & 651 & -133 & -11.96 \\
\hline WF17 & $8 / 11 / 95$ & 223 & & & & 398 & 104.0 & 2.01 & 677 & 53.7 & 6.83 & & & 674 & -132 & -12.29 \\
\hline WF18 & $8 / 21 / 95$ & 233 & 80.3 & 6.67 & & 404 & 104.0 & 2.25 & 702 & 36.4 & 6.87 & & & 728 & -140 & -14.44 \\
\hline WF19 & $8 / 26 / 95$ & 238 & 83.2 & 6.97 & & 435 & 107.0 & 2.27 & 699 & 30 & 6.71 & & & 698 & -142 & -14.98 \\
\hline WF20 & $9 / 1 / 95$ & 244 & 85.8 & 7.44 & & 423 & 108.0 & 2.02 & 694 & 25.6 & 5.83 & & & 706 & -142 & -15.15 \\
\hline WF21 & $9 / 8 / 95$ & 251 & 82.9 & 7.73 & & 410 & 101.0 & 2.27 & 694 & 24.8 & 8.92 & & & 719 & -142 & -14.97 \\
\hline
\end{tabular}

${ }^{1}$ Laboratory chemical analyses by D. Counce

2 Isotope analyses by L. D. White

${ }^{3}$ For Julian days 173 through 202 the listed temperatures are $2{ }^{\circ} \mathrm{C}$ higher than those recorded in the field to correct for an instrumental error in calibration. 
Table 2. Estimated reservoir temperatures using silica and $\mathrm{Na} / \mathrm{K}$ chemical geothermometers

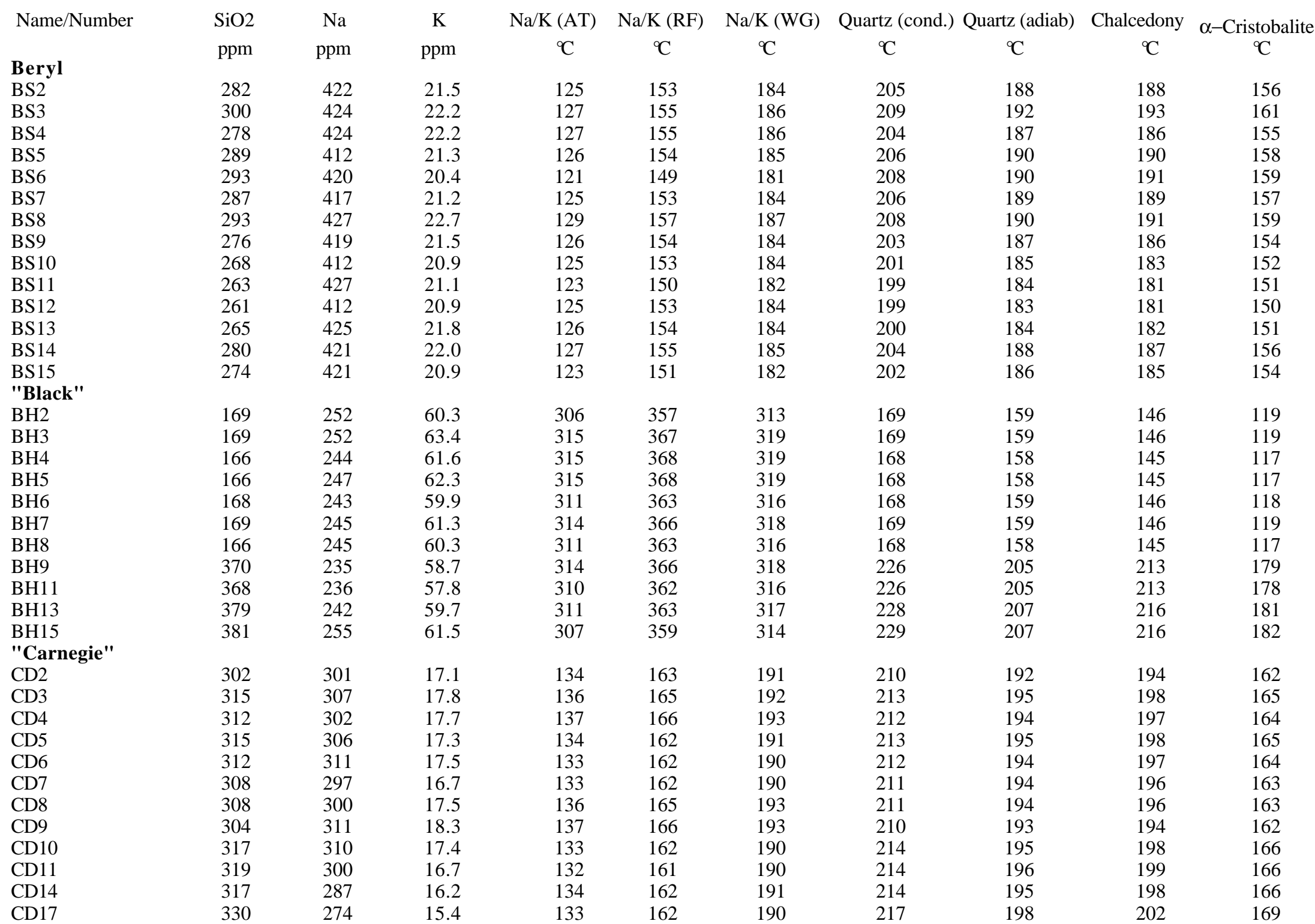




\begin{tabular}{|c|c|c|c|c|c|c|c|c|c|c|}
\hline Name/Number & $\mathrm{SiO} 2$ & $\mathrm{Na}$ & $\mathrm{K}$ & $\mathrm{Na} / \mathrm{K}(\mathrm{AT})$ & $\mathrm{Na} / \mathrm{K}(\mathrm{RF})$ & $\mathrm{Na} / \mathrm{K}(\mathrm{WG})$ & Quartz (cond.) & Quartz (adiab) & Chalcedony & $\alpha-$ Cristobali \\
\hline Cistern & ppm & ppm & ppm & ${ }^{\circ} \mathrm{C}$ & ${ }^{\circ} \mathrm{C}$ & ${ }^{\circ} \mathrm{C}$ & ${ }^{\circ} \mathrm{C}$ & ${ }^{\circ} \mathrm{C}$ & ${ }^{\circ} \mathrm{C}$ & ${ }^{\circ} \mathrm{C}$ \\
\hline $\mathrm{CS} 2$ & 589 & 335 & 70.1 & 284 & 332 & 299 & 268 & 238 & 264 & 224 \\
\hline CS3 & 595 & 332 & 70.4 & 286 & 334 & 301 & 269 & 238 & 266 & 225 \\
\hline CS4 & 597 & 336 & 70.8 & 285 & 333 & 300 & 269 & 239 & 266 & 226 \\
\hline CS5 & 589 & 332 & 70.5 & 286 & 335 & 301 & 268 & 238 & 264 & 224 \\
\hline CS6 & 578 & 334 & 70.4 & 285 & 333 & 300 & 266 & 236 & 262 & 222 \\
\hline CS7 & 580 & 335 & 71.5 & 287 & 336 & 301 & 266 & 236 & 263 & 223 \\
\hline CS8 & 578 & 332 & 70.3 & 286 & 334 & 300 & 266 & 236 & 262 & 222 \\
\hline CS9 & 606 & 338 & 72.4 & 288 & 336 & 302 & 271 & 240 & 268 & 227 \\
\hline CS10 & 586 & 333 & 71.1 & 287 & 336 & 301 & 267 & 237 & 264 & 224 \\
\hline CS11 & 569 & 331 & 70.4 & 287 & 335 & 301 & 264 & 235 & 260 & 221 \\
\hline CS12 & 567 & 337 & 75.6 & 295 & 345 & 306 & 264 & 235 & 260 & 220 \\
\hline CS13 & 614 & 345 & 73.5 & 287 & 335 & 301 & 272 & 241 & 269 & 229 \\
\hline $\mathrm{CS} 14$ & 582 & 346 & 72.1 & 284 & 331 & 299 & 267 & 237 & 263 & 223 \\
\hline CS 15 & 571 & 348 & 72.2 & 283 & 331 & 298 & 265 & 235 & 261 & 221 \\
\hline CS16 & 578 & 352 & 76.0 & 289 & 338 & 302 & 266 & 236 & 262 & 222 \\
\hline CS17 & 578 & 350 & 77.8 & 294 & 343 & 305 & 266 & 236 & 262 & 222 \\
\hline CS20 & 574 & 336 & 74.8 & 294 & 343 & 306 & 265 & 236 & 261 & 222 \\
\hline CS21 & 535 & 326 & 71.7 & 292 & 341 & 304 & 259 & 231 & 253 & 214 \\
\hline $\mathrm{CS} 22$ & 533 & 325 & 66.3 & 280 & 328 & 297 & 258 & 230 & 253 & 214 \\
\hline $\mathrm{CS} 23$ & 535 & 308 & 67.1 & 291 & 339 & 303 & 259 & 231 & 253 & 214 \\
\hline $\mathrm{CS} 24$ & 505 & 302 & 61.0 & 279 & 326 & 296 & 253 & 226 & 246 & 208 \\
\hline CS25 & 492 & 292 & 60.7 & 283 & 331 & 299 & 251 & 225 & 243 & 206 \\
\hline $\mathrm{CS} 26$ & 479 & 277 & 57.4 & 283 & 330 & 298 & 248 & 223 & 240 & 203 \\
\hline $\mathrm{CS} 27$ & 452 & 264 & 56.5 & 288 & 336 & 301 & 243 & 219 & 234 & 197 \\
\hline $\mathrm{CS} 28$ & 492 & 272 & 60.5 & 294 & 343 & 305 & 251 & 225 & 243 & 206 \\
\hline $\mathrm{CS} 29$ & 484 & 249 & 53.0 & 287 & 335 & 301 & 249 & 223 & 242 & 204 \\
\hline CS30 & 460 & 259 & 53.2 & 281 & 329 & 297 & 245 & 220 & 236 & 199 \\
\hline CS31 & 482 & 271 & 58.6 & 289 & 338 & 303 & 249 & 223 & 241 & 204 \\
\hline CS32 & 484 & 270 & 58.6 & 290 & 339 & 303 & 249 & 223 & 242 & 204 \\
\hline CS33 & 499 & 297 & 63.6 & 288 & 336 & 302 & 252 & 226 & 245 & 207 \\
\hline CS34 & 496 & 298 & 63.7 & 288 & 336 & 301 & 252 & 225 & 244 & 207 \\
\hline CS35 & 507 & 305 & 67.9 & 294 & 343 & 306 & 254 & 227 & 247 & 209 \\
\hline CS36 & 469 & 284 & 61.8 & 290 & 339 & 303 & 247 & 221 & 238 & 201 \\
\hline CS37 & 484 & 292 & 65.5 & 295 & 345 & 306 & 249 & 223 & 242 & 204 \\
\hline \multicolumn{11}{|l|}{ Double Bulger } \\
\hline DB4 & 535 & 470 & 94.2 & 277 & 324 & 295 & 259 & 231 & 253 & 214 \\
\hline DB5 & 428 & 405 & 82.7 & 280 & 328 & 297 & 238 & 215 & 228 & 192 \\
\hline DB6 & 456 & 498 & 107 & 288 & 337 & 302 & 244 & 219 & 235 & 198 \\
\hline DB7 & 541 & 495 & 99.2 & 277 & 324 & 295 & 260 & 231 & 254 & 215 \\
\hline
\end{tabular}




\begin{tabular}{|c|c|c|c|c|c|c|c|c|c|c|}
\hline Name/Number & $\mathrm{SiO} 2$ & $\mathrm{Na}$ & $\mathrm{K}$ & $\mathrm{Na} / \mathrm{K}(\mathrm{AT})$ & $\mathrm{Na} / \mathrm{K}(\mathrm{RF})$ & $\mathrm{Na} / \mathrm{K}(\mathrm{WG})$ & Quartz (cond.) & Quartz (adiab) & Chalcedony & $\alpha-$ Cristobalite \\
\hline & ppm & $\mathrm{ppm}$ & ppm & ${ }^{\circ} \mathrm{C}$ & ${ }^{\circ} \mathrm{C}$ & ${ }^{\circ} \mathrm{C}$ & ${ }^{\circ} \mathrm{C}$ & ${ }^{\circ} \mathrm{C}$ & ${ }^{\circ} \mathrm{C}$ & ${ }^{\circ} \mathrm{C}$ \\
\hline DB8 & 469 & 455 & 90.4 & 276 & 323 & 294 & 247 & 221 & 238 & 201 \\
\hline DB9 & 524 & 551 & 107 & 273 & 319 & 292 & 257 & 229 & 251 & 212 \\
\hline DB10 & 492 & 833 & 144 & 256 & 300 & 280 & 251 & 225 & 243 & 206 \\
\hline DB11 & 501 & 771 & 151 & 274 & 320 & 292 & 253 & 226 & 245 & 208 \\
\hline DB12 & 511 & 877 & 167 & 270 & 316 & 290 & 254 & 227 & 248 & 210 \\
\hline DB13 & 452 & 671 & 121 & 262 & 306 & 284 & 243 & 219 & 234 & 197 \\
\hline DB14 & 518 & 721 & 138 & 270 & 316 & 290 & 256 & 228 & 249 & 211 \\
\hline DB15 & 492 & 687 & 125 & 263 & 308 & 285 & 251 & 225 & 243 & 206 \\
\hline DB16 & 531 & 762 & 134 & 258 & 302 & 282 & 258 & 230 & 252 & 213 \\
\hline DB17 & 458 & 596 & 117 & 274 & 321 & 293 & 244 & 220 & 235 & 199 \\
\hline DB18 & 452 & 491 & 96.0 & 274 & 320 & 292 & 243 & 219 & 234 & 197 \\
\hline \multicolumn{11}{|c|}{ Perpetual Spouter } \\
\hline PS2 & 285 & 405 & 47.9 & 207 & 244 & 246 & 205 & 189 & 189 & 157 \\
\hline PS3 & 291 & 428 & 50.1 & 206 & 243 & 245 & 207 & 190 & 190 & 159 \\
\hline PS4 & 287 & 428 & 52.7 & 212 & 250 & 250 & 206 & 189 & 189 & 157 \\
\hline PS5 & 291 & 419 & 50.6 & 209 & 247 & 248 & 207 & 190 & 190 & 159 \\
\hline PS6 & 282 & 406 & 48.8 & 209 & 246 & 248 & 205 & 188 & 188 & 156 \\
\hline PS7 & 289 & 394 & 47.5 & 209 & 247 & 248 & 206 & 190 & 190 & 158 \\
\hline PS10 & 319 & 406 & 49.1 & 209 & 247 & 248 & 214 & 196 & 199 & 166 \\
\hline PS12 & 312 & 410 & 51.2 & 213 & 251 & 251 & 212 & 194 & 197 & 164 \\
\hline PS14 & 330 & 432 & 52.3 & 210 & 247 & 248 & 217 & 198 & 202 & 169 \\
\hline PS16 & 319 & 417 & 50.2 & 209 & 247 & 248 & 214 & 196 & 199 & 166 \\
\hline \multicolumn{11}{|l|}{ Porkchop } \\
\hline $\mathrm{PC} 2$ & 516 & 390 & 76.3 & 274 & 320 & 292 & 255 & 228 & 249 & 211 \\
\hline PC3 & 582 & 396 & 80.0 & 279 & 326 & 296 & 267 & 237 & 263 & 223 \\
\hline PC4 & 597 & 402 & 82.3 & 281 & 328 & 297 & 269 & 239 & 266 & 226 \\
\hline PC5 & 721 & 385 & 80.3 & 284 & 331 & 299 & 288 & 253 & 290 & 247 \\
\hline PC6 & 721 & 395 & 86.6 & 292 & 341 & 304 & 288 & 253 & 290 & 247 \\
\hline PC7 & 719 & 388 & 87.7 & 297 & 346 & 307 & & & 290 & 247 \\
\hline PC8 & 725 & 414 & 89.4 & 289 & 338 & 302 & 289 & 254 & 291 & 248 \\
\hline PC9 & 717 & 392 & 95.0 & 308 & 360 & 315 & 288 & 253 & 289 & 246 \\
\hline PC 10 & 693 & 410 & 92.3 & 296 & 346 & 307 & 284 & 250 & 285 & 243 \\
\hline PC 11 & 681 & 410 & 88.1 & 288 & 337 & 302 & 282 & 249 & 283 & 240 \\
\hline PC12 & 693 & 426 & 87.3 & 281 & 328 & 297 & 284 & 250 & 285 & 243 \\
\hline PC14 & 685 & 418 & 82.3 & 275 & 321 & 293 & 283 & 249 & 283 & 241 \\
\hline PC 15 & 646 & 428 & 89.6 & 284 & 332 & 299 & 277 & 245 & 276 & 235 \\
\hline PC20 & 666 & 456 & 89.5 & 274 & 321 & 293 & 280 & 247 & 280 & 238 \\
\hline PC21 & 678 & 459 & 96.0 & 284 & 332 & 299 & 282 & 248 & 282 & 240 \\
\hline PC 22 & 666 & 495 & 99.0 & 277 & 324 & 295 & 280 & 247 & 280 & 238 \\
\hline PC23 & 633 & 498 & 94.0 & 268 & 314 & 289 & 275 & 243 & 273 & 232 \\
\hline
\end{tabular}




\begin{tabular}{|c|c|c|c|c|c|c|c|c|c|c|}
\hline Name/Number & $\mathrm{SiO} 2$ & $\mathrm{Na}$ & $\mathrm{K}$ & $\mathrm{Na} / \mathrm{K}(\mathrm{AT})$ & $\mathrm{Na} / \mathrm{K}(\mathrm{RF})$ & $\mathrm{Na} / \mathrm{K}(\mathrm{WG})$ & Quartz (cond.) & Quartz (adiab) & Chalcedony & $\alpha-$ Cristobal \\
\hline & ppm & ppm & ppm & ${ }^{\circ} \mathrm{C}$ & ${ }^{\circ} \mathrm{C}$ & ${ }^{\circ} \mathrm{C}$ & ${ }^{\circ} \mathrm{C}$ & ${ }^{\circ} \mathrm{C}$ & ${ }^{\circ} \mathrm{C}$ & ${ }^{\circ} \mathrm{C}$ \\
\hline $\begin{array}{l}\text { Sulphur Dust } \\
\text { SD2 }\end{array}$ & 240 & 252 & 54.9 & \multicolumn{7}{|c|}{ Sulphur Dust } \\
\hline SD3 & 244 & 252 & 58.4 & 301 & 351 & 310 & 194 & 179 & $\begin{array}{l}1 / 4 \\
175\end{array}$ & $\begin{array}{l}144 \\
145\end{array}$ \\
\hline SD4 & 242 & 267 & 61.2 & 299 & 349 & 309 & 193 & 179 & 174 & 144 \\
\hline SD5 & 246 & 260 & 60.4 & 301 & 351 & 310 & 195 & 180 & 176 & 145 \\
\hline SD6 & 242 & 261 & 58.9 & 296 & 346 & 307 & 193 & 179 & 174 & 144 \\
\hline SD7 & 250 & 263 & 59.0 & 295 & 345 & 306 & 196 & 181 & 177 & 147 \\
\hline SD8 & 229 & 261 & 61.0 & 302 & 353 & 311 & 189 & 176 & 170 & 140 \\
\hline SD9 & 253 & 273 & 63.5 & 301 & 352 & 310 & 197 & 182 & 178 & 148 \\
\hline SD10 & 255 & 249 & 59.9 & 307 & 358 & 314 & 197 & 182 & 179 & 148 \\
\hline SD11 & 270 & 274 & 61.6 & 296 & 345 & 307 & 201 & 185 & 184 & 153 \\
\hline SD12 & 263 & 253 & 60.5 & 306 & 357 & 313 & 199 & 184 & 181 & 151 \\
\hline SD13 & 255 & 259 & 60.4 & 302 & 352 & 310 & 197 & 182 & 179 & 148 \\
\hline SD14 & 253 & 254 & 61.2 & 307 & 359 & 314 & 197 & 182 & 178 & 148 \\
\hline SD15 & 285 & 257 & 64.6 & 315 & 367 & 319 & 205 & 189 & 189 & 157 \\
\hline SD16 & 274 & 269 & 61.5 & 298 & 348 & 308 & 202 & 186 & 185 & 154 \\
\hline \multicolumn{11}{|l|}{ "Wistful" } \\
\hline WF4 & 736 & 405 & 103 & 317 & 369 & 320 & 290 & 255 & 293 & 250 \\
\hline WF5 & 715 & 410 & 107 & 321 & 375 & 323 & 287 & 252 & 289 & 246 \\
\hline WF6 & 713 & 406 & 104 & 318 & 371 & 321 & 287 & 252 & 289 & 246 \\
\hline WF7 & 753 & 422 & 109 & 319 & 373 & 322 & 293 & 257 & 296 & 252 \\
\hline WF8 & 751 & 413 & 107 & 320 & 373 & 322 & 292 & 256 & 296 & 252 \\
\hline WF9 & 770 & 393 & 99.0 & 315 & 367 & 319 & 295 & 258 & 299 & 255 \\
\hline WF10 & 713 & 391 & 101 & 319 & 373 & 322 & 287 & 252 & 289 & 246 \\
\hline WF11 & 730 & 402 & 101 & 315 & 367 & 319 & 289 & 254 & 292 & 249 \\
\hline WF12 & 646 & 390 & 101 & 320 & 373 & 322 & 277 & 245 & 276 & 235 \\
\hline WF13 & 544 & 374 & 105 & 335 & 390 & 331 & 260 & 232 & 255 & 216 \\
\hline WF14 & 554 & 392 & 111 & 336 & 392 & 332 & 262 & 233 & 257 & 218 \\
\hline WF15 & 651 & 434 & 113 & 321 & 374 & 322 & 278 & 245 & 277 & 235 \\
\hline WF16 & 651 & 415 & 105 & 316 & 368 & 319 & 278 & 245 & 277 & 235 \\
\hline WF17 & 674 & 398 & 104 & 322 & 375 & 323 & 281 & 248 & 281 & 239 \\
\hline WF18 & 728 & 404 & 104 & 319 & 372 & 321 & 289 & 254 & 291 & 248 \\
\hline WF19 & 698 & 435 & 107 & 311 & 363 & 316 & 285 & 251 & 286 & 243 \\
\hline WF20 & 706 & 423 & 108 & 317 & 370 & 320 & 286 & 251 & 287 & 245 \\
\hline WF21 & 719 & 410 & 101 & 311 & 363 & 316 & 288 & 253 & 290 & 247 \\
\hline
\end{tabular}

$\mathrm{Na} / \mathrm{K}(\mathrm{AT})$ - Temperature estimated using the equation of Truesdell (1976)

$\mathrm{Na} / \mathrm{K}(\mathrm{RF})$ - Temperature estimated using the equation of Fournier (1979)

$\mathrm{Na} / \mathrm{K}$ (WG) - Temperature estimated using the equation of Giggenbach (1988)

Quartz (cond) - Temperature estimated using the equation of Fournier and Potter (1982), assuming conductive cooling and silica controlled by the solubility of quartz Quartz (adiab) - Temperature estimated using the equation of Fournier and Potter (1982), assuming adiabatic cooling and silica controlled by the solubility of quartz Chalcedony - Temperature estimated using the equation of Fournier (1985), assuming conductive cooling and silica controlled by the solubility of chalcedony

$\alpha$-Cristobalite - Temperature estimated using the equation of Fournier (1985), assuming conductive cooling and silica controlled by the solubility of $\alpha$-cristobalite 